\title{
VISUALISASI “RAMADAN” DALAM KOMIK DAKWAH FACEBOOK THE MUSLIM SHOW TAHUN 2019
}

\author{
Muhammad Hildan Azizi \\ STID Al-Hadid, Surabaya \\ hildan@stidalhadid.ac.id
}

\begin{abstract}
Abstrak: Studi ini bertujuan untuk menguraikan penggambaran "Ramadan" yang mengacu pada kategori tanda menurut Peirce, yakni ikon, indeks, dan simbol pada komik dakwah bertema bulan Ramadan yang dipublikasi oleh akun Facebook The Muslim Show tahun 2019. The Muslim Show adalah komikus yang hasil karyanya telah menjangkau banyak negara, pesan-pesan dakwah dalam simbol semiotika komik yang digunakannya telah berhasil menjangkau umat Islam secara luas. Studi ini menggunakan pendekatan kualitatif dengan menganalisis delapan komik yang diunggah akun facebook The Muslim Show pada bulan April-Mei 2019. Semiotika visual menjadi alat analisis dalam mendeskripsikan makna dan tanda/simbol yang digunakan. Hasil studi ini menunjukkan: (1) Ramadan adalah bulan yang dinanti umat muslim dengan suka cita juga dapat membangun emosi positif, bermanfaat untuk mengubur kebiasaan buruk, dan perlu keimanan yang kuat untuk menempuhnya, serta banyak tantangan fisik dan psikis yang menyertai baik dalam kehidupan sehari-hari maupun ketika ibadah. (2) Penggunaan simbol terhadap barang-barang yang sering digunakan orang-orang pada zaman ini, serta warna sebagai indeks menjadikan komik ini secara universal dapat dipahami oleh khalayak di manca negara.
\end{abstract}

Kata kunci: Semiotika Visual, Komik Strip, Dakwah, The Muslim Show.

"Ramadan" Visualization In The 2019 Facebook Da'wah Comic Of The Muslim Show. Abstract: This study aims to expound the depiction of "Ramadan", referring to the category of signs, according to Pierce, namely icons, indexes, and symbols, in the da'wah comic with the theme of Ramadan published on the Facebook account of the Muslim Show in 2019. The Muslim Show is a comic artist whose works have reached many countries. The da'wah messages in comic semiotic symbols he uses have succeeded in extensively reaching Muslim communities. It uses qualitative approach by analyzing eight comics uploaded from April to May 2019. Visual semiotics is used to be an analytic tool for describing the meanings and signs / symbols used. It indicates that (1) Ramadan is the month that Moslems look forward to with joy. It can also build positive emotion and bury the bad habits. it is necessary to go through this month with a strong faith. There are a lot of physical and psychological challenges throughout daily life and acts of worship; (2) the uses of symbols for items often used by peole today, as well as colors as an indexes, make this comic universally understandable by Facebook viewers/users abroad.

Key words: Visual Semiotics, Strip Comic, Da'wah, The Muslim Show 


\section{Pendahuluan}

Uraian makna tanda atas bulan "Ramadan" menjadi tujuan dalam studi ini. Kategori tanda Peirce yakni ikon, indeks, dan simbol menjadi acuan dalam mengkaji komik dakwah bertema bulan Ramadan yang dipublikasi oleh akun Facebook The Muslim Show tahun 2019. Komik adalah salah satu media dakwah yang relevan dalam mengikuti perkembangan teknologi informasi, salah satunya adalah komik strip. Sebab komik yang pada awalnya menggunakan saluran media cetak seperti buku-buku dan majalah, namun seiring perkembangan media sosial, sedikit banyak mendorong para komikus untuk beralih saluran. Bagaimana pun, media sosial lebih banyak menarik audiens daripada media cetak. $^{1}$

Komik bukan akhir dari hasrat manusia untuk menceritakan pengalamannya melalui gambar dan tanda. Penggunaan grafis di atas teks yang mungkin pada awalnya hanya sekedar tanda demi memenuhi kepuasan estetika, pada akhirnya dapat pula menjadi pengganti kata atau pengisahan verbal. ${ }^{2}$ Komik salah satu bentuk cabang seni rupa yang bisa bersifat menghibur, mendidik, dan mengandung pesan tertentu tergantung si pembuat komik untuk memuat pesan

\footnotetext{
1. Romario dan Lisda Aisyah, "Komik Islam Di Media Sosial Instagram: Dakwah Kreatif Melalui Komik," Islamuna, Vol. 6, No. 2 (2019), 98-99, doi: http://ejournal.iainmadura.ac.id/index.php/islamuna/ article/download/2588/1551

2 . Didiek Rahmanadji, "Awal Eksistensi Komik Indonesia, Sebagai Produk Budaya Nasional," Universitas Negeri Malang, diakses pada 8 Februari 2020, http://jurnalonline.um.ac.id/data/artikel/artikelF79F984D53BF7B C7A2D27DA1CFB68F87.pdf.

3. Dwiki Nugroho Mukti dan Salamun, "Penciptaan Karya Komik Alternatif," Jurnal Pendidikan Seni Rupa, Vol. 3, No. 2 (2015), 16, doi:
}

tertentu di dalam komiknya. ${ }^{3}$ Artinya, komik merupakan hasil karya seni yang bersifat menyenangkan sehingga, memunculkan kenyamanan pada pembaca, hal inilah yang menyebabkan pesan implisit lebih mudah disampaikan melalui komik. Begitu juga, nilai-nilai atau pesan dakwah dapat pula diekstraksi ke dalam komik. ${ }^{4}$

Namun, tidak semua nilai ajaran Islam dapat diekstraksi dengan baik dalam suatu komik. Misalnya seperti kasus The 99 Teskheel Comics yang menjadi kontroversi karena penggambaran pahlawan super sebagai identitas dewa Muslim dan karakter berpakaian burka. Serial komik tersebut akhirnya cepat dilarang di Arab Saudi, dan rencana pembuatan serial animasi untuk tayang di AS tak pernah terwujud. ${ }^{5}$ Salah satu komik dakwah yang cukup terkenal adalah karya Noredine Allam dalam serial komik The Muslim Show. Terkenal karena Allam ini adalah komikus sekaligus pimpinan redaksi penerbitan BDouin yang berasal dari Perancis, tetapi hasil karyanya dapat menjangkau umat muslim di banyak negara. Akun facebook resmi The Muslim Show memiliki 854 ribu penyuka serta bahkan mendapat rating lima atau sempurna dari 829 responden. $^{6}$

https://jurnalmahasiswa.unesa.ac.id/ index.php/va/article/download/10512/10225

4. Rulli Nasrullah dan Novita Intan Sari, "Komik sebagai Media Dakwah: Analisis Semiotika Kepemimpinan Islam dalam Komik 'Si Bujang'," Jurnal Ilmu Dakwah, Vol. 6, No. 19 (2012), 27, doi: http://iournal.uinsgd.ac.id/index.php/idaihs/article/vi ewFile/325/440

5. Umi Nur Fadhilah, "9 Komik Superhero Muslim, republika.com, diakses pada 27 Januari 2021, https://republika.co.id/berita/dunia-islam/islamnusantara/17/11/20/ozpyud335-9-komik-superheromuslim.

6. Lihat profil akun Facebook The Muslim Show ini: https://web.facebook.com/themuslimshow/about. 
Hal ini berarti secara visual, ilustrasi yang digunakan Allam dapat diterima oleh audiens di manca negara dengan karakternya yang heterogen. Serta, pilihan ilustrasi yang digunakan tetap sesuai dengan ajaran Islam, sehingga tidak ada pertentangan atasnya. Bahkan di Indonesia, penerbit Mizan telah mencetak buku komik terjemahan dari The Muslim Show ini. ${ }^{7}$ Dalam salah satu pernyataannya, Noredine Allam menegaskan, "...I have decided to dedicate the majority of my time on entertaining, educational and informative projects (all the while continuing to produce "mini comics" promoting proper, Islamic behaviour)." 8 Bahwa, ia hanya akan membuat komik yang informatif dan mengedukasi namun tetap menghibur dengan muatan konten mengenai kebiasaan-kebiasaan yang islami.

Salah satu topik yang menarik adalah ketika The Muslim Show mengunggah serangkaian komik di akun facebook officialnya dengan tema Ramadan pada tahun 2019. ${ }^{9}$ Secara, konten di mana tiap negara bahkan daerah memiliki kearifan tersendiri dalam memaknai Ramadan, tetapi The Muslim Show mampu mengambil sisi yang dapat diterima umat muslim di beberapa negara atau setidaknya tidak mendapat penolakan. Bagi para praktisi dakwah khususnya dalam bidang visual, tentu hal ini bisa menjadi

\footnotetext{
7. Salah satunya pada judul buku berikut ini: https://mizanstore.com/ramadhan ala muslim show 17564.

8. Noredine Allam, "Announcement By Noredine Allam of Muslim Show," le-bdouin.com, diakses pada 8 Februari 2020, https://www.lebdouin.com/announcement-by-noredine-allam-ofmuslim-show/.

9. Dimulai pada posting tertanggal 7 April 2019 berikut ini:

https://web.facebook.com/themuslimshow/posts/20 39546229500774 dan berarkhir pada posting tertanggal 25 Mei 2019 berikut ini:
}

pelajaran hikmah dan inspirasi simbolsimbol semiotika yang dapat digunakan namun tetap tidak menghilangkan karakter khas masing-masing desainer. Beberapa pengikut postingan The Muslim Show menyampaikan ulasannya terhadap unggahan tentang Ramadan itu. Diantaranya adalah: "Whoever you are made this, thank you, from my heart," tulis Kimzana Sari. ${ }^{10}$ "This page is great, may Allah bless all of you," tulis Huda Rafa. ${ }^{11}$ "It give me tears of joy... SUBHANALLAH," tulis M Xakir Kayani. ${ }^{12}$ Menarik untuk mengulas makna yang terkandung dalam dakwah tersebut dan serangkaian tanda visual yang digunakan hingga banyak kalangan memberikan respons positif terhadap kehadiran komik tersebut. ${ }^{13} \mathrm{Hal}$ ini, sesuai dengan karakter dalam dakwah yakni menyeru pada kebaikan dengan menggunakan jalan persuasi atau kesadaran.

Oleh karena itu, studi ini mencoba untuk mengkaji hal terkait bagaimana semiotika visual penggambaran bulan Ramadan dalam komik dakwah akun facebook The Muslim Show pada tahun 2019. Bahwa, studi ini hendak mengkaji mengenai makna tandatanda yang digunakan dalam menyimbolkan bulan Ramadan pada komik tersebut.

Alat analisis yang paling tepat dalam studi mengenai hal tersebut adalah semiotika visual. Sebab komik dibuat menggunakan

https://web.facebook.com/themuslimshow/posts/21 13636038758459

10. Lihat kolom komentar pada unggahan berikut: https://web.facebook.com/themuslimshow/posts/20 88707704584626.

11. Lihat kolom komentar pada unggahan berikut: https://web.facebook.com/themuslimshow/posts/20 86997731422290.

12. Lihat kolom komentar pada unggahan berikut: https://web.facebook.com/themuslimshow/posts/20 39546229500774.

13. Ibid. 
elemen verbal dan elemen visual untuk berkomunikasi, dimana kedua hal ini membentuk suatu bahasa visual. Caldwell menjelaskan bahwa: The visual elements used within comics are often associated with specific meanings. 'Readers of comics learn how to associate certain repetitive pictorial elements with specific meanings, effectively treating them as linguistic units'. ${ }^{14}$

Beberapa riset terdahulu telah banyak mengungkap studi terkait semiotika visual. Hanya saja masih minim riset yang berfokus pada visualisasi dalam dakwah, khususnya komik strip. Beberapa di antaranya yakni, Disertasi berjudul Visual Semiotics: A Study of Images in Japanese Advertisementes karya Rumiko Oyama. ${ }^{15}$ Juga ada studi berjudul Analisis Semiotika Visual Pada Poster Ngayogjazz 2011-2014 karya Maria Giovanie dan Elda Franzia. ${ }^{16}$ Juga terdapat, Semiotika Visual Logo RSU Surya Husadha Denpasar karya I Nyoman Jayanegara. ${ }^{17}$ Terdapat studi yang meneliti aspek semiotika simbol keislaman, namun berada pada ruang iklan/bukan dakwah seperti penelitian Representasi Pakaian Muslimah dalam Iklan karya Murti Candra Dewi. ${ }^{18}$ Ada pun studi yang berfokus dalam bidang

\footnotetext{
14. Joshua Caldwell, "Comic panel layout: A Peircean analysis," Studies in Comics, Vol. 2, No. 2 (2011), 318, doi: https://doi.org/10.1386/stic.2.2.317 1

15. Rumiko Oyama, "Visual Semiotics: A Study of Images in Japanese Advertisements," (Disertasi Institute of Education University of London, November 1998), 1305.

16. Maria Giovanie Anggasta dan Elda Franzia, "Analisis Semiotika Visual Pada Poster Ngayogjazz 2011-2014," Dimensi, Vol. 13, No. 2 (2015), 177-192, doi: https://trijurnal.lemlit.trisakti.ac.id/dimensi/article/d ownload/57/57

17. I Nyoman Jayanegara, "Semiotika Visual Logo RSU Surya Husadha Denpasar," Jurnal Bahasa Rupa, Vol. 1, No. 1 (Oktober 2017), 11-16, doi: https://doi.org/10.31598/bahasarupa.v1i1.138

18 . Murti Candra Dewi, "Representasi Pakaian Muslimah dalam Iklan (Analisis Semiotika Charles
}

dakwah yakni Komik sebagai Media Dakwah: Analisis Semiotika Kepemimpinan Islam dalam Komik "Si Bujang" karya Rulli dan Nasrullah, ${ }^{19}$ teknik analisis yang digunakan mengkombinasi unsur narasi tokoh protagonis dan antagonis sebagai unit analisis untuk mendeskripsikan nilai kepemimpinan Islam. Sedangkan dalam studi ini, teknik analisis berfokus pada simbol/tanda visual yang ditampilkan tanpa kombinasi unsur lain sebagai unit analisis. Sedangkan, penelitian yang benar-benar hampir serupa dengan studi ini pernah dilakukan oleh Yuliana Rakhmawati dalam The Muslim Show: Soft Contra "Labeling" Melalui... ${ }^{20}$ Studi tersebut mencoba menelaah simbol-simbol semiotika yang digunakan dalam wacana Islam minoritas. Sedangkan, studi ini spesifik membahas mengenai Ramadan.

Kajian ini menggunakan pendekatan deskriptif kualitatif, artinya merincikan temuan-temuan yang nampak pada komik strip secara kualitatif. Data primer bersumber dari akun facebook resmi milik The Muslim Show di @TheMuslimShow, dari rentang waktu bulan April-Mei tahun 2019. Terdapat 8 (delapan) komik strip tentang

Sanders Peirce pada Iklan Kosmetik Wardah di Tabloid Nova)", Jurnal Komunikasi Profetik, Vol. 06, No. 2 (Oktober 2013), 63-82, doi: http://ejournal.uinsuka.ac.id/isoshum/profetik/article/download/1171/ $\underline{1081}$

19. Rulli Nasrullah dan Novita Intan Sari, “Komik sebagai Media Dakwah: Analisis Semiotika Kepemimpinan Islam dalam Komik 'Si Bujang'," IImu Dakwah: Academic Journal for Homiletic Studies, Vol. 6, No. 1 (Juni 2012), 24-40, doi http://journal.uinsgd.ac.id/index.php/idajhs/article/vi ewFile/325/440

20. Yuliana Rakhmawati, "The Muslim Show: Soft Contra "Labeling" Melalui Media Sosial", Jurnal Komunikasi, Vol. IX, No. 1 (Maret 2015), 1-12, doi: https://eco-

entrepreneur.trunojoyo.ac.id/komunikasi/article/vie wFile/1147/971 
bulan Ramadan yang diunggah pada rentang waktu itu. ${ }^{21}$ Penggalian data menggunakan teknik dokumentasi, yakni mengumpulkan dokumen komik berdasarkan dari sumber data. Analisis data menggunakan alat semiotika visual, yakni berfokus pada unit analisis ikon, simbol, atau indeks yang digunakan dalam sumber data. Teknik uji keabsahan penelitian berdasarkan pada uji kredibilitas dengan teknik meningkatkan ketekunan serta uji transferbilitas dengan memberikan uraian yang rinci, jelas, dan sistematis dalam laporan penelitian. ${ }^{22}$

\section{Semiotika Visual}

Semiotika visual adalah cabang baru semiotika yang muncul di tahun 90 -an. Tetap berpijak pada tanda sebagai kata kunci semiotika, hingga pada akhirnya tanda bisa diwujudkan dalam bentuk kata, suara, bahkan gambar visual. Oleh karena itu, Lester dalam Parsa menjelaskan bahwa semiotika visual adalah suatu metode dalam memahami makna mendalam di balik objek atau gambar, sebab segala bentuk representasi fisik ialah tanda yang bermakna di atas objek itu sendiri. ${ }^{23}$ Dalam teorinya, Peirce dalam Harrison menyebut bahwa terdapat tiga kategori terkait tanda: ikon, indeks, dan simbol. ${ }^{24}$

21. Ada 8 unggahan komik dalam akun Facebook The Muslim Show terkait tentang Ramadan setelah unggahan pertama berikut ini: https://web.facebook.com/themuslimshow/posts/20 39546229500774.

22. John W. Creswell dan Dana L. Miller, "Determining Validity in Qualitative Inquiry," Theory Into Practice, Vol. 39, No. 3 (Summer, 2000), 128-129, doi: https://doi.org/10.1207/s15430421tip3903 2

23. Alev Fatos Parsa, "Visual Semiotics: How Still Images Mean? Interpreting Still Images by Using Semiotic Approaches," 2nd International Symposium
Peirce dalam Sumbo menjelaskan bahwa, sebuah gambar adalah ikon jika gambar/tanda yang digunakan memiliki kemiripan dengan objek yang diwakilinya atau dapat juga disebutkan bahwa tanda tersebut memiliki ciri-ciri yang sama dengan fakta realitasnya. Misalnya, peta Yogyakarta adalah ikon dari realitas batas wilayah Yogyakarta. 25 Sedangkan, Peirce sebagaimana dijelaskan Harrison telah menjelaskan bahwa suatu gambar adalah indeks jika dapat dikenali, bukan karena ada kesamaan dengan suatu objek atau orang, tetapi karena kita memahami hubungan antara gambar dan konsep yang dianutnya. Sebuah baling-baling cuaca, misalnya, tidak memiliki kemiripan dengan aspek cuaca apa pun, namun ia mewakili konsep angin. Indeks Web yang umum adalah panah yang mengarah ke atas untuk menunjukkan bagian atas halaman Web. Tanda-tanda indeks dapat membingungkan dan, oleh karena itu, sering memerlukan teks untuk menyertainya. Inilah sebabnya mengapa panah menunjuk ke atas pada halaman yang dapat digulir sering juga diberi label, "Top of Page." 26

Sedangkan, gambar adalah simbol ketika tidak memiliki koneksi visual atau konseptual ke objek atau orang. Kami tahu arti gambar hanya karena konvensi; itu adalah sesuatu yang telah kita pelajari. Sebuah kata, misalnya, adalah simbol karena kata itu tidak

Communication in The Millennium: A Dialogue, (2004), 843-853.

24. Claire Harrison, "Visual Social Semiotics: Understanding How Still Images Make Meaning," Technical Communication, Vol. 50, No. 1 (Februari 2003), 50, doi: https://bit.ly/38C5xXW

25. Sumbo Tinarbuko, "Semiotika Analisis Tanda Pada Karya Desain Komunikasi Visual", Nirmala, Vol. 5, No. 1 (Januari 2003), 34, doi: https://doi.org/10.9744/nirmana.5.1

26 . Claire Harrison, "Visual Social Semiotics: Understanding How Still Images Make Meaning", 50. 
menyerupai apa artinya, juga tidak memiliki hubungan indeksik dengan apa yang ditandakannya. Ambil kata rose. Itu tidak terlihat seperti mawar atau memiliki hubungan apa pun dengan konsep mawar. Simbol Web umum adalah garis di bawah kata atau frasa yang digunakan untuk menunjukkan tautan. ${ }^{27}$

Dalam kajian ini, konsep ikon, indeks, dan simbol Peirce akan digunakan sebagai identifikasi awal semiotika yang digunakan dalam tiap-tiap komik strip. Sehingga, dapat dipahami secara empiris tanda yang digunakan dalam mengomunikasikan pesan agar tidak multi-persepsi. Setelah itu, hasil identifikasi tersebut coba dihubungkan antar elemen tanda (ikon, indeks, simbol) dalam membentuk suatu makna dengan konteks sosial budaya yang berlaku dengan struktur penandaan yang digunakan.

\section{Komik Strip}

Bonnef dalam Soedarso menjelaskan komik merupakan sebuah susunan gambar dan kata yang bertujuan untuk memberikan informasi yang ingin disampaikan kepada pembaca. Sebuah komik selalu memanfaatkan ruang gambar dengan tata letak. Hal tersebut agar gambar membentuk cerita, yang dituangkan dalam bentuk dan tanda. Komik juga termasuk karya sastra, yaitu sastra bergambar. ${ }^{28}$

\footnotetext{
27. Ibid.

28. Nick Soedarso, "Komik: Karya Sastra Bergambar," Humaniora, Vol. 6, No. 4 (Oktober 2015), 497, doi: https://journal.binus.ac.id/index.php/Humaniora/arti cle/download/3378/2757

29. Essy Syam, "Crayon Shin-Chan: Apakah Komik Jepang Mendidik?" Jurnal IImu Budaya, Vol. 5, No. 1 (2008), 42 , doi: https://journal.unilak.ac.id/index.php/jib/article/view $\not 885 / 630$
}

Lebih lanjut, ia juga menjelaskan bahwa kemunculan komik telah menjadi sasaran kritik dan tudingan orang tua. Komik dinilai sebagai bacaan yang kurang memberikan nilai pendidikan. Sebab tidak semua komik ditulis untuk dikonsumsi oleh anak-anak dan tidak pula semua komik menyajikan nilainilai moral, sebagaimana kajian Syam yang nyatakan misalnya dalam komik Crayon ShinChan, banyak ucapan tidak pantas/tidak sopan kepada orang tua atau orang lain. ${ }^{29}$

Namun saat ini, kehadiran komik sudah menjadi salah satu media komunikasi yang ikut berperan sebagai sarana dalam memberikan informasi maupun pendidikan yang terkandung di dalamnya. Kehadiran komik sebagai media hiburan pada saat ini berkembang menjadi media pesan lainnya, seperti iklan promosi, media pendidikan, dan media penyampaian lainnya yang memberikan sebuah suasana baru dalam sebuah pesan. ${ }^{30}$ Dalam perkembangannya, dikenal pula jenis komik strip yang terbagi menjadi beberapa panel. Komik strip memiliki perbedaan yang khas dengan karya fiksional pada umumnya, sebab subjek dalam komik strip lebih bersumber pada pengalaman pembaca. Oleh Bitzer dalam Turner disebutkan bahwa komik strip asks for ideas already possessed by the audience on topics known to them, requiring their participation in order to be completed. ${ }^{31}$

\footnotetext{
30. Nick Soedarso, "Komik: Karya Sastra Bergambar," Humaniora, Vol. 6, No. 4 (Oktober 2015), 497, doi https://journal.binus.ac.id/index.php/Humaniora/arti cle/download/3378/2757

31. Kathleen J. Turner, "Comic strips: A rethorical perspective", Central States Speech Journal, Vol. 28 No. 1 (1977), 28, doi: https://doi.org/10.1080/10510977709367916
} 
Studi tentang komik juga turut mengikuti perkembangan praktis. Terdapat beberapa konsep struktur yang dapat digunakan dalam mengkaji komik strip. Cohn memaparkan sedikitnya terdapat lima struktur dalam komik, yakni struktur grafis, struktur konseptual, struktur spasial, struktur kejadian, dan struktur naratif. ${ }^{32}$

Struktur grafis adalah suatu hal tertentu yang terbentuk dari garis, kurva, dan bentuk berdasarkan pada rekognisi perseptual. Dalam komik strip, secara visual terkadang tidak hanya satu gambar, tetapi gambar sekuensial yang memiliki komponen navigasional. Struktur konseptual adalah suatu makna individual tertentu yang terbentuk dari struktur grafis, bergantung pada memori individual yang serupa dengan objek termaksud. Struktur spasial adalah suatu kesamaan/perbedaan struktur grafis tertentu baik dalam/antar panel berdasarkan sudut pandang aerial tertentu yang mengkombinasikan antara informasi geometris dengan pengetahuan abstrak terhadap suatu konsep tertentu. Struktur konseptual adalah suatu makna individual tertentu yang terbentuk dari struktur grafis, bergantung pada memori individual yang serupa dengan objek termaksud. Struktur kejadian adalah suatu hubungan tertentu dalam bentuk kejadian antar konsep-konsep grafis yang berada dalam ruang spasial tertentu. Struktur naratif adalah hubungan kisah kronologis yang terbentuk antar panel dengan komponen navigasional tertentu. ${ }^{33}$

Dalam perkembangannya, komik strip ini dapat dimuat dalam versi digital, selain versi

32. Neil Cohn, "Visual Narrative Structure," Cognitive Science 34 (2013), 414-415.

33. Ibid.

34. Zetizen, "Komik Cetak vs Komik Online, Apa Kelebihanny?"

Jawapos.com cetak. Hal ini, memang memberi pengalaman membaca yang berbeda. Sebagaimana dijelaskan oleh Chris Lie, founder "Reon Comics," bahwa komik versi cetak tetap dipertahankan agar membangun hubungan erat antara komikus dan pembacanya. Sebab, komik cetak punya bentuk yang nyata, dapat disimpan, dan dapat dikoleksi dalam bentuk fisik. Selain itu, kualitas komik cetak pun seringkali lebih terjaga, karena penerbitnya selektif dalam meilih komikus. Sedangkan, komik digital memiliki keunggulan pada kemudahan akses dan cenderung gratis. ${ }^{34}$

\section{Semiotika Bulan Ramadan dalam The Muslim Show}

Berikut ini merupakan hasil analisis semiotika visual pada masing-masing komik strip.

\section{Komik Strip “Welcoming Ramadan"}

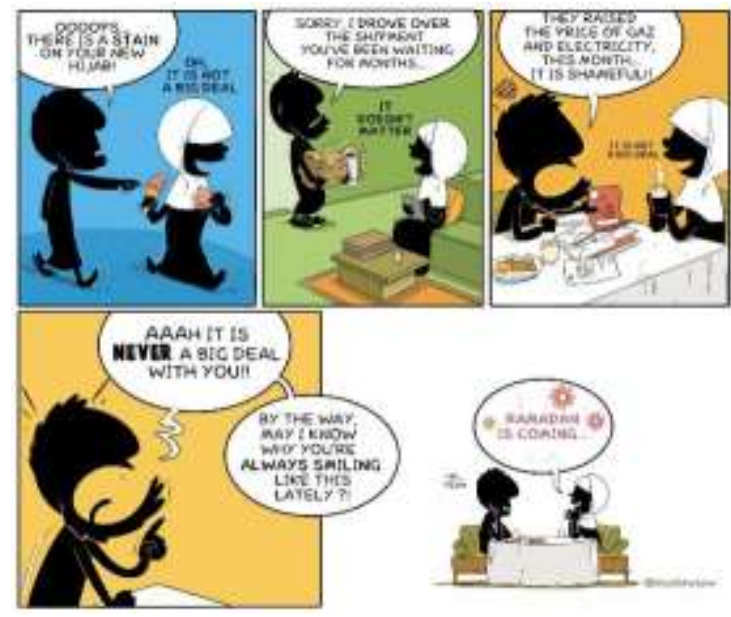

Gambar 1 Menyambut Ramadan, Sumber: https://web.facebook.com/themuslimshow/posts/203 9546229500774

https://zetizen.jawapos.com/show/1553/komikcetak-vs-komik-online-apa-kelebihannya. (diakses tanggal 06 Januari, 2020). 
Identifikasi tanda pada komik strip di atas adalah sebagai berikut:

Tabel 1 - Identifikasi Tanda dalam Komik Strip Satu

\begin{tabular}{ll}
\hline \multicolumn{1}{c}{ Jenis } & \multicolumn{1}{c}{ Identifikasi } \\
\hline Ikon & 1. Eskrim. \\
& 2. Kardus penyok. \\
& 3. Kertas tagihan. \\
& 4. Sosok pria hitam. \\
& 5. Sosok wanita hitam berjilbab. \\
& 6. Meja dan kursi. \\
Indeks & 1. Noda eskrim. \\
& 2. Gelas berasap. \\
& 3. Bunga sekitar teks. \\
Simbol & Keseluruhan teks percakapan.
\end{tabular}

Pada panel pertama, latar belakang berwarna biru muda dengan gradasi bagian bawah agak gelap, sedangkan bagian atas agak cerah. Hal ini menandakan bagian gelap seperti dataran tempat kedua sosok berpijak, sedangkan bagian cerah seperti situasi di atas dataran. Hanya saja memang dibuat sederhana tentang situasi di atas dataran.

Terdapat sosok siluet hitam laki-laki berjenggot mengenakan gamis, serta sosok siluet perempuan mengenakan jubah hitam dan jilbab putih. Di tangan kanan si perempuan memegang benda segitiga coklat ber-topping warna merah muda menyerupai bulatan yang menguncup di atasnya, sedangkan tangan kiri si perempuan memegang ujung bawah jilbab yang sebagiannya terdapat bercak merah muda. Telunjuk tangan kiri si laki-laki mengarah pada jilbab si perempuan. Mulut si laki-laki tampak membuka sedikit. Terdapat pop-up teks yang keluar dari arah si laki-laki dengan isi teks "OOOOPS... THERE IS A STAIN ON YOUR NEW HIJAB." Jika diterjemahkan

${ }^{35}$ Cambridge Dictionary, s.v. "There is a stain on your new hijab," berarti: "Oooops... Ada noda pada hijab baru anda." 35

Hal ini memberi petunjuk baru bahwa jilbab yang dikenakan si perempuan adalah jilbab baru. Serta bercak merah muda di ujung bawah jilbab si perempuan adalah noda. Tampaknya jika dihubungkan dengan benda coklat-merah muda di tangan kanan si perempuan, maka benda itu dapat dimaknai sebagai es krim cone strawberry yang dapat menempel sebagai noda di suatu pakaian. Sedangkan, di atas kepala si perempuan terdapat teks: "OH, IT IS NOT A BIG DEAL." Jika diterjemahkan berarti, "Oh, itu bukan masalah besar." ${ }^{36}$ Mulut si perempuan pun terbuka lebar seraya tersenyum. Teks di atas kepala perempuan ini merupakan bentuk respons terhadap teks si laki-laki sebelumnya, khususnya dikuatkan dengan telunjuk tangan kiri si laki-laki yang mengarah pada jilbab si perempuan. Bahwa, noda es krim di jilbab baru si perempuan dianggap bukan permasalahan besar bagi si perempuan.

Pada panel kedua, terdapat sosok siluet hitam laki-laki berjenggot mengenakan gamis panjang hingga bawah lutut. Kedua tangannya membopong balok coklat yang tak beraturan setinggi perut-dada dan terdapat detail bagian putih yang menjulur keluar dari dalam balok itu. Kepala si laki-laki mendongak dan terdapat tetes air putih di pelipisnya. Terdapat pula garis-garis hitam kecil di sekitar kepala si laki-laki. Mulutnya terbuka sedikit seperti menggumam. Terdapat pop-up teks yang keluar dari arah si laki-laki dengan isi teks: "SORRY, I DROVE OVER THE SHIPMENT YOU'VE BEEN WAITING

https://dictionary.cambridge.org/translate/. (diakses tanggal 27 November, 2020). ${ }^{36} \mathrm{Ibid}$. 
FOR MONTHS..." Jika diterjemahkan berarti: "Maaf, saya melaju di atas pengiriman yang anda telah tunggu selama berbulanbulan." ${ }^{37}$

Teks verbal itu menjadi petunjuk makna atas balok coklat yang sedang dibopongnya, bahwa benda itu adalah sebuah paket milik si perempuan dengan kondisi yang telah hancur. Begitu juga dengan tanda tetes air putih di pelipisnya bermakna keringat, serta guratan garis hitam di sekitar kepala berarti tanda bahwa si laki-laki khawatir terhadap suatu hal. Terlebih pula kekhawatiran ini dikuatkan dengan besar katup mulut si lakilaki yang terbuka sempit seperti menggumam.

Di depan laki-laki itu ada sosok siluet hitam perempuan mengenakan jubah panjang dan jilbab putih. Si perempuan duduk di bangku panjang dan terdapat bulatan kuning kecil di antara tubuhnya dan sandaran kursi. Tangan kanan perempuan menggenggam samping benda kotak kecil abu-abu, sedangkan tangan kirinya berada di atas permukaan depan kotak itu. Terdapat guratan garis setengah lingkaran di belakang kepala si perempuan. Wajah si perempuan menghadap laki-laki dan mulutnya terbuka lebar seperti tersenyum.

Terdapat teks yang berada di depan wajah perempuan, isinya: "IT DOESN'T MATTER." Yang jika diterjemahkan berarti: "Itu tidak masalah." 38 Teks ini merupakan jawaban perempuan terhadap laki-laki. "Itu," yang dimaksud perempuan adalah kondisi paket yang hancur. Sehingga, dapat dimaknai bahwa si perempuan tidak

37 Cambridge Dictionary, s.v. "Sorry I drove over the shipment you've been waiting for a months," mempermasalahkan atas hancurnya paket yang telah ia nanti-nanti selama sebulan akibat kelalaian si laki-laki.

Hal ini pula, memberi petunjuk terhadap simbol-simbol yang ada pada diri perempuan. Bahwa, makna "tidak mempermasalahkan" itu diwujudkan dengan sosok perempuan yang masih tetap duduk melakukan aktivitasnya terhadap benda kotak kecil abu-abu di tangannya, pun guratan garis hitam setengah lingkaran di belakang kepalanya berarti ia hanya menoleh saja tanpa reaksi berlebihan.

Pada panel ketiga, terdapat latar belakang berwarna kuning. Di depan latar belakang itu terdapat dua sandaran kursi coklat. Pada layer paling depan terdapat separuh bagian meja persegi panjang berwarna putih. Di atas meja terdapat beberapa benda seperti gelas, piring beserta makanan di atasnya, serta berserakan benda menyerupai kertas dan amplop. Terdapat sosok siluet hitam laki-laki setengah badan di antara layer meja dan kursi pertama. Tangan kanannya mengepal dan berpangku pada meja. Tangan kirinya mengangkat benda persegi panjang berwarna merah dengan terdapat guratan garis-garis hitam serta putih di dalamnya. Mulut si laki-laki terbuka lebar jika dibandingkan dua panel sebelumnya. Terdapat pula guratan garis-garis hitam kecil di sekitar kepalanya, juga terdapat guratan garis spiral di atas kepalanya.

Terdapat pop-up teks yang keluar dari arah si laki-laki dengan isi teks: "THEY RAISED THE PRICE OF GAZ AND ELECTRICITY THIS MONTH... IT IS SHAMEFUL!!" Jika

https://dictionary.cambridge.org/translate/. (diakses tanggal 27 November, 2020).

38. Ibid. 
diterjemahkan berarti: "Mereka menaikkan harga gas dan listrik bulan ini... Ini memalukan!!"39

Hal ini, dapat menjadi petunjuk makna atas kertas merah yang dipegang si laki-laki dan kertas lain yang berserakan di atas meja, bahwa hal itu berarti seperti halnya suratsurat tagihan bulanan terkait gas dan listrik. Sedangkan, mulutnya yang menganga lebar, guratan-guratan garis hitam serta spiral hitam di sekitar kepalanya berarti emosi kekecewaan yang dibalut dengan kemarahan. Hal ini, juga tampak dari tanda kepalan tangan kanannya yang dipangku di atas meja.

Sedangkan, di depan si laki-laki terdapat sosok siluet hitam perempuan berjilbab putih sedang mengangkat gelas yang mengeluarkan tanda asap di atasnya. Kedua siku tangannya berpangku di atas meja dan mulutnya terbuka lebar seraya tersenyum. Terdapat teks di depan wajah si perempuan bertuliskan: "IT IS NOT A BIG DEAL." Kira-kira berarti: "Ini bukan masalah besar." ${ }^{40}$ Teks tersebut berarti si perempuan menganggap kenaikan harga tagihan bulanan terkait listrik dan gas bukanlah suatu permasalahan. Makna ini juga diperkuat dengan tanda senyum dimulutnya, juga sikap tangan yang santai dalam menggengam gelas yang mengeluarkan asap seperti akan menyeruput teh dengan tenang.

Selanjutnya, panel keempat ini merupakan kelanjutan dari panel ketiga, sebab latar belakangnya tetap berwarna kuning dengan aksen properti meja putih yang hanya

\footnotetext{
39. Cambridge Dictionary, s.v. "They raised the price of gas and electricity this month. It's shameful," https://dictionary.cambridge.org/translate/. (diakses tanggal 27 November, 2020)
}

ditampakkan ujungnya saja sebagai tempat pangku tangan. Kali ini hanya terdapat satu sosok siluet hitam laki-laki. la tampak mengepalkan tangan kanannya di atas meja dan mengangkat jari telunjuk kiri ke arah atas. Mulutnya terbuka sangat lebar jika dibandingkan dengan tiga panel sebelumnya, bahkan seperti tampak lidah di dalam mulutnya. Banyak guratan-guratan garis hitam di sekitar kepala dan tangannya, bahkan terdapat guratan garis putih besar sepanjang belakang punggungnya.

Terdapat pop-up teks yang keluar dari arah si laki-laki dengan isi teks: "AAAH IT IS NEVER A BIG DEAL WITH YOU!! BY THE WAY, MAY I KNOW WHY YOU'RE ALWAYS SMILING LIKE THIS LATELY ?!" Jika diterjemahkan berarti: "Aaah Ini bukan masalah besar denganmu. Ngomong-ngomong, boleh aku tahu mengapa kau selalu tersenyum seperti ini akhir-akhir ini?!" ${ }^{41}$ Teks verbal itu dapat menjadi petunjuk bahwa menganganya mulut si laki-laki merupakan luapan emosi, terlebih pula dikuatkan dengan tanda guratan-guratan garis hitam kecil maupun putih besar di sekitar tubuhnya. Secara tidak langsung memperkuat makna teks bahwa si laki-laki sangat merasa aneh terhadap sikap perempuan yang menganggap permasalahan noda di jilbab baru, rusaknya paket kiriman yang dinanti-nanti, serta naiknya harga tagihan listrik dan gas bulanan; bukanlah permasalahan besar.

Pada panel kelima, latar tampak putih bahkan tanpa garis pembatas di sekelilingnya. Terdapat meja berbentuk lingkaran yang diapit dengan kursi 
bertangkai pendek berwarna coklat tanpa sandaran khusus. Hanya saja terdapat dua bantal hijau di atas kursi yang berperan sebagai penyandar.Terdapat sosok siluet hitam perempuan sedang duduk di salah satu kursi. Kakinya tak tampak, sepertinya berada di bawah meja. Kedua siku tangannya berpangku di atas meja, kedua tangannya mengepal di depan dagunya. Mulutnya terbuka seperti tersenyum. la menghadap ke arah si laki-laki.

Terdapat pop-up teks yang keluar dari arah si perempuan dengan isi teks: "RAMADAN IS COMING..." Jika diterjemahkan berarti berarti: "Ramadan akan datang...." ${ }^{22}$ Disertai dengan gambar bunga-bunga berwarna merah muda di sekitar teksnya. Pop-up teks pada panel terakhir ini merupakan jawaban atas pertanyaan si laki-laki pada panel keempat. Hal ini, memberi petunjuk makna terhadap tanda sikap duduk yang berarti nuansa informal, serta kepalan tangan dan siku tangannya yang berpangku di atas meja yang berarti confident atau percaya diri, ${ }^{43}$ terlebih jelas terdapat tanda mulut yang terbuka seperti tersenyum. Sehingga, bermakna si perempuan menyambut bulan Ramadan yang akan segera datang dengan percaya diri. Juga terdapat tanda bungabunga merah muda di sekitar teks yang dapat dimaknai sebagai emosi yang berbunga-bunga atau kiasan dari bahagia.

Selain itu, terdapat sosok siluet hitam lakilaki sedang duduk di salah satu kursi. Kakinya tak tampak berada di bawah meja. la menyanggah dagunya dengan tangan kanannya dan sikunya berada di atas meja.

42. Cambridge Dictionary, s.v. "Ramadan is coming," https://dictionary.cambridge.org/translate/. (diakses tanggal 27 November, 2020).

43. Allan and Barbara Pease, The Definitive Book of Body Languange: How to read others' thought by their
Sedangkan, tangan kirinya tak tampak. la menghadap pada si perempuan, mulutnya terbuka sedikit seperti tersenyum. Serta terdapat teks bertuliskan: "HA... YEAH" Di belakang kepalanya.

Pop-up teks yang keluar dari si perempuan lebih besar daripada teks dari si laki-laki, maka teks dari si laki-laki ini adalah respons atas teks si perempuan. Hal tersebut, berarti si laki-laki setuju dengan teks serta sikap si perempuan, bahwa Ramadan akan datang dan perlu disambut dengan suka cita. Hal ini, juga dikuatkan dengan senyum si laki-laki dan sikap duduk serta bersanggah dagu yang dilakukannya, yang berarti juga penuh percaya diri. ${ }^{44}$

Sehingga secara umum, komik strip pertama ini bermakna bahwa si perempuan tidak menganggap bahwa noda es krim di jilbab barunya, rusaknya paket kiriman yang telah dinantinya, dan naiknya harga tagihan listrik dan gas bulanan sebagai permasalahan besar; sebab ada sesuatu hal yang lebih besar yang akan datang yakni bulan Ramadan, bulan yang dinanti-nanti dengan penuh suka cita oleh semua orang. Hal ini, berkaitan erat dengan tradisi Islam maupun nusantara dalam menyambut Ramadan. Sebagaimana kajian Royanulloh dan Komari yang menyatakan bahwa Ramadan terbiasa disambut dengan penuh suka cita. Oleh karena itu, bulan Ramadan diduga berkaitan pula dengan kebahagiaan. Lebih lanjut mereka memaparkan, bahwa terdapat korelasi positif antara datangnya bulan Ramadan dengan emosi positif, serta berkorelasi negatif dengan emosi negatif.

gestures (Australia: Pease International, 2004), 132133.

44. Ibid. 
Tentu dapat disimpulkan bahwa datangnya bulan Ramadan berkaitan dengan peningkatan kebahagiaan seorang muslim. ${ }^{45}$

\section{Komik Strip "Benefit of Ramadan"}

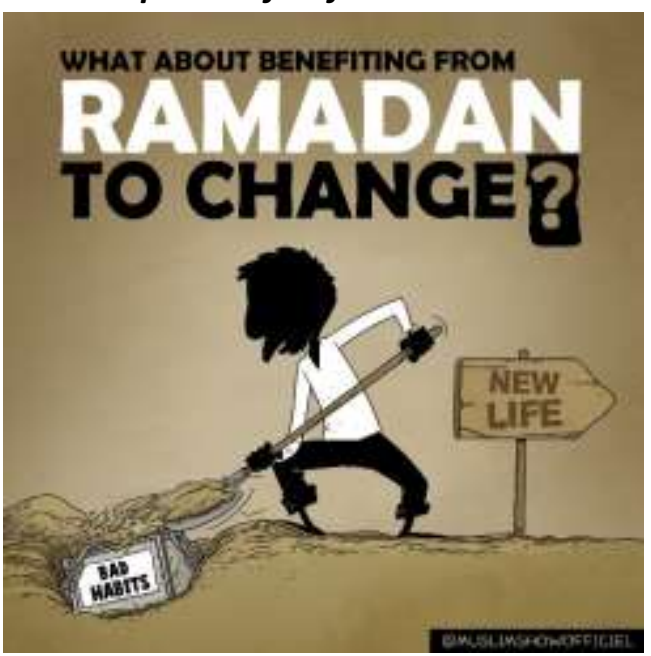

Gambar 2 Manfaat Ramadan, Sumber: https://web.facebook.com/themuslimshow/posts/208 4049908383739

Identifikasi tanda pada komik strip dua adalah sebagai berikut:

\begin{tabular}{|c|c|}
\hline Jenis & Identifikasi \\
\hline Ikon & $\begin{array}{l}\text { 1. Sosok pria hitam. } \\
\text { 2. Sekop. } \\
\text { 3. Kotak besi. } \\
\text { 4. Papan kayu penunjuk arah. } \\
\text { 5. Tanah pasir. }\end{array}$ \\
\hline Indeks & Bahasa tubuh mengubur. \\
\hline Simbol & $\begin{array}{l}\text { 1. Teks "Bad Habits". } \\
\text { 2. Teks “New Life". } \\
\text { 3. Teks judul. }\end{array}$ \\
\hline
\end{tabular}

Pada strip ini terdapat sosok siluet hitam laki-laki mengenakan baju putih lengan panjang dan celana panjang hitam yang digulung ujunganya hingga sedikit di bawah lutut. la berdiri tanpa alas kaki di atas dataran seperti berbentuk gumpalan-

45. Royanullah dan Komari, "Bulan Ramadan dan Kebahagiaan Seorang Muslim," Jurnal Psikologi Islam dan Budaya, Vol. 2, No. 2 (Oktober 2019), 127, doi: http://journal.uinsgd.ac.id/index.php/ipib/article/do wnload/5587/3427 gumpalan tanah berwarna coklat muda. Kakinya berjarak lebar-lebar, tangannya memegang benda seperti sekop. Tangan kirinya menggenggam ujung gagang sekop sedangkan tangan kanannya menggenggam gagang yang dekat dengan besi sekop. Tampak terdapat pasir di atas besi sekopnya. Di bawah besi sekop itu terdapat balok abuabu besar yang disekelilingnya seperti terdapat rantai dengan warna senada. Di bagian depan balok itu terdapat tempelan kertas putih dan teks hitam bertuliskan: "BAD HABITS." Jika diterjemahkan berarti: "Kebiasaan Buruk." ${ }^{46}$ Posisi balok ini berada di cekungan galian dataran tanah. Terdapat gundukan tanah di sekitar galian itu.

Sedangkan, di sisi sebelah kiri si laki-laki terdapat benda seperti papan kayu berbentuk segi lima yang meruncing di sebelah kanannya. Papan kayu itu tampak menempel di depan tongkat kayu berwarna senada yang menancap di dataran tanah. Dalam papan-kayu itu terdapat teks bertuliskan: "NEW LIFE." Jika diterjemahkan berarti: "Kehidupan Baru." ${ }^{47}$ Di atas kepala si laki-laki terdapat teks besar yang hampir memakan seperempat total panel. Teks itu bertuliskan: "WHAT ABOUT BENEFITING FROM RAMADAN TO CHANGE?" Jika diterjemahkan berarti: "Bagaimana dengan manfaat dari Ramadan untuk berubah?" 48 Teks itu dapat menjadi petunjuk makna atas tanda-tanda di bawahnya. Bahwa, jawaban atas pertanyaan tersebut adalah bulan Ramadan mampu membuat manusia mengubur atau meninggalkan kebiasaan buruknya untuk menuju pada kehidupan baru yang lebih baik. Tanda mulut si laki-laki

46 . Cambridge Dictionary, s.v. "Bad habits," https://dictionary.cambridge.org/translate/. (diakses tanggal 27 November, 2020)

47. Ibid.

48. Ibid. 
yang terbuka datar dan kepala menunduk seakan menyimbolkan suatu ketidaksetujuan ${ }^{49}$ terhadap apa yang dikubur.

Sebagaimana kajian Andi Hidayat yang memaparkan bahwa puasa Ramadan dapat melepaskan diri dari kebiasaan-kebiasan lama yang ingin diubah. ${ }^{50}$ Begitu juga, membangun kebiasaan baik seperti penjelasan Irsyadul Ibad dan Bakti Andrian yang menyatakan puasa Ramadan membangun kebiasaan melatih kesabaran, menanamkan rasa kasih sayang, bersikap jujur, melatih kedisiplinan, dan mendidik sikap amanah, serta kepekaan sosial. ${ }^{51}$

\section{Komik Strip "Journey of Ramadan"}

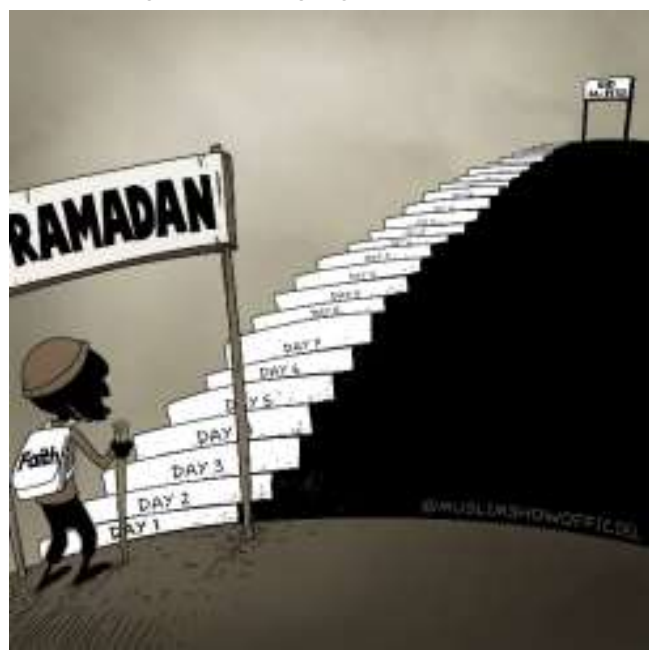

Gambar 3 Perjalanan Ramadan, Sumber: https://web.facebook.com/themuslimshow/post $s / 2081599745295422$
Identifikasi tanda pada komik strip di atas adalah sebagai berikut:

Tabel 3 Identifikasi Tanda dalam Komik Strip Tiga

\begin{tabular}{lll}
\hline \multicolumn{1}{c}{ Jenis } & \multicolumn{1}{c}{ Identifikasi } \\
\hline Ikon & 1. & Sosok pria hitam. \\
& 2. Tas ransel. \\
& 3. Tiang papan nama. \\
& 4. Anak tangga. \\
Indeks & Bahasa tubuh pegang tongkat dan \\
& menatap jauh ke atas. \\
Simbol & 1. Teks "Faith". \\
& 2. Teks "Ramadan". \\
& 3. Teks "Day 1" dan seterusnya. \\
& 4. Teks "Eid al-Fitr".
\end{tabular}

Latar belakang strip ini berwarna coklat gelap. Seperempat latar bagian bawah lebih gelap daripada tigaperempat bagian atas. Hal ini sepertinya hendak menandakan suatu dataran tempat sosok berpijak dan situasi di atas dataran tersebut.

Terdapat sosok siluet hitam laki-laki berjanggut yang berada di bagian sisi kiri strip. la mengenakan baju lengan panjang berwarna coklat muda, peci bundar dengan warna senada, dan celana panjang tujuh per delapan. Tangan kanannya menggenggam ujung atas tongkat yang menghujam ke dataran di bawah. la juga membawa tas ransel putih di belakang punggungnya. Tas ransel itu bertuliskan teks: "FAITH" yang dapat berarti keyakinan atau keimanan. Dihadapannya terdapat gapura tinggi seperti terbuat dari kayu. Terdiri dari papan panjang besar yang dijunjung dengan tongkat di kedua sisinya setinggi hampir dua kali tinggi sosok si laki-laki. Papan kayu itu bertuliskan

\footnotetext{
51. Bakti Andrian, “Nilai-nilai Pendidikan Islam dalam Pengamalan Puasa Ramadhan Menurut Tafsir AlMisbah," (Skripsi-UIN Raden Intan Lampung, 2019), Abstrak; Irsyadul Ibad, "Nilai-Nilai Kependidikan dalam Pengamalan Ibadah Puasa Ramadan," (Kajian AlQur'an Surat al-Baqarah Ayat 183-187), (Skripsi-IAIN Salatiga, 2015), Abstrak.

49. Allan and Barbara Pease, The Definitive Book of Body Languange: How to read others' thought by their gestures (Australia: Pease International, 2004), 234 235.

50. Moh. Andi Hidayat, "Nilai-nilai Pendidikan Islam dalam Ibadah Puasa Ramadan," (Skripsi-IAIN Jember, 2016), Abstrak.
} 
teks: "RAMADAN" yang berarti bulan Ramadan.

Di hadapan laki-laki itu pula atau di belakang gapura itu terdapat banyak anak tangga yang mengarah pada bagian atas semacam bukit. Tujuh anak tangga itu sekitar setinggi sosok si laki-laki. Tiap anak tangga terdapat teks bertuliskan: "DAY 1, DAY 2," dan seterusnya hingga berhenti di teks "DAY 19." Masih terdapat beberapa anak tangga selanjutnya namun tanpa berisi tulisan teks apapun. Di bagian atas bukit terdapat gapura serupa dengan yang di bawah, hanya saja dengan ukuran yang lebih kecil sebab terikat oleh susunan titik geometri tiga dimensi sehingga seakan-akan gapura di atas sangat jauh. Hanya saja berbeda dengan gapura di bawah, gapura di atas bertuliskan teks: "EID AL-FITR" yang berarti berarti Idul Ftri.

Berdasarkan tanda-tanda tersebut di atas dapat dimaknai bahwa sosok laki-laki digambarkan sebagai seorang muslim berpeci dan berjanggut. la adalah musafir jika merujuk pada penggunaan tongkat serta tas ransel yang digunakan. Gapura "Ramadan" di hadapannya berarti ia akan memasuki bulan Ramadan. Sedangkan, sejumlah anak tangga di hadapannya dengan teks bertuliskan hari-hari pertama hingga kesembilan belas dan seterusnya, menggambarkan hari-hari yang harus ditempuh oleh seorang muslim dengan usaha yang cukup seperti halnya seseorang yang sedang menapaki tiap anak tangga. Di puncak atau akhir anak tangga terdapat gapura "Idul Fitri" sebagai tanda berakhirnya bulan Ramadan serta usaha ekstra yang

52. Hasballah Thaib dan Zamakhsyari Hasballah, La'allakum Tattaquun Seratus Satu Jalan Menuju Taqwa Yang Harus Dilatih Selama Ramadhan (Medan: Wal Ashri Publishing, 2014), 2. perlu dilakukan oleh seorang muslim karena datarannya bersifat mendatar. Dalam mencapai itu semua, seorang muslim membutuhkan keimanan dan/atau keyakinan yang cukup sebagai bekal dalam menapakinya.

Tentu hal ini, selaras dengan penjelasan Hasballah Thaib dan Zamakhsyari bahwa niat, doa, dan tekad yang kuat sangatlah penting untuk melaksanakan ibadah di bulan Ramadan dengan sebaik-baiknya. Mereka juga menambahkan fikih puasa Yusuf Qardawi yang menjelaskan maksud niat di sini adalah berniat melaksanakan ibadah demi melaksanakan perintah Allah dan taqarub kepada-Nya. ${ }^{52}$ Taqarub yang artinya mendekatkan diri kepada Allah dengan berbagai bentuk ibadah yang tak terbatasi oleh waktu khusus tertentu. ${ }^{53}$

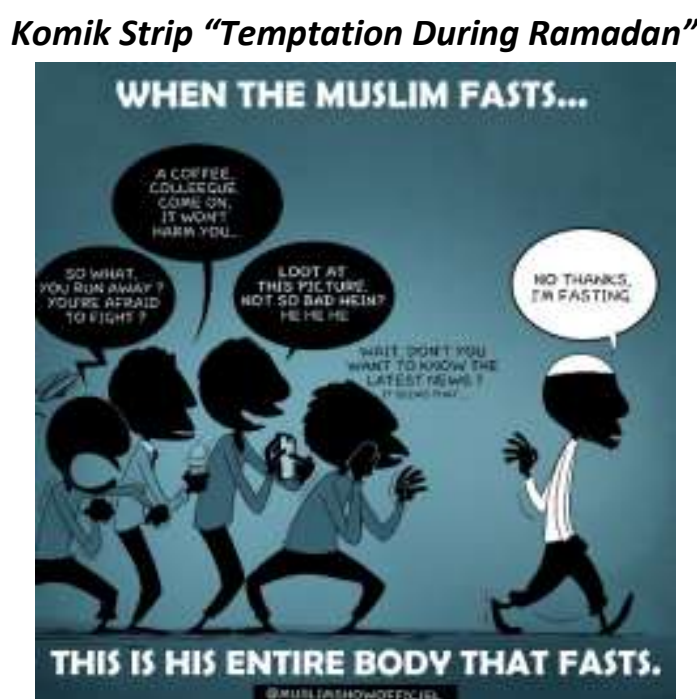

Gambar 4 Godaan Kala Ramadan, Sumber: https://web.facebook.com/themuslimshow/post s/2086997731422290

53. Alhafiz Kurniawan, "Taqarub Tidak Mesti Hari Tertentu," nu.or.id, https://www.nu.or.id/post/read/44991/taqarubtidak-mesti-hari-tertentu. (diakses tanggal 11 Januari, 2021). 
Identifikasi tanda pada komik strip di atas adalah sebagai berikut:

Tabel 4 Identifikasi Tanda dalam Komik Strip Empat

\begin{tabular}{lll}
\hline \multicolumn{1}{c}{ Jenis } & \multicolumn{1}{c}{ Identifikasi } \\
\hline Ikon & 1. $\begin{array}{l}\text { Sosok pria hitam berpeci dan baju } \\
\text { putih. }\end{array}$ \\
& 2. $\begin{array}{l}\text { Empat sosok pria hitam berbaju } \\
\text { biru. }\end{array}$ \\
Indeks & Bahasa tubuh menggerakkan tangan. \\
Simbol & $\begin{array}{l}\text { 1. } \\
\text { Teks percakapan empat sosok. } \\
\text { 2. Teks percakapan sosok baju } \\
\text { putih. }\end{array}$ \\
\hline
\end{tabular}

Di bagian atas strip ini terdapat teks besar berwarna putih bertuliskan: "WHEN THE MUSLIM FASTS..." Jika diterjemahkan berarti: "Ketika muslim berpuasa..." 54 Agaknya secara tekstual dapat diartikan sesuai dengan terjemahnya. Lebih lanjut perlu dipahami tanda-tanda yang digunakan di bagian tengah. Terdapat empat sosok siluet hitam laki-laki yang berbaris. Mereka mengenakan baju berwarna biru dongker gelap. Empat sosok itu digambarkan membawa benda dan memiliki perilaku yang berbeda satu sama lainnya.

Sosok pertama, berada barisan paling belakang. la sedang melebarkan kakinya dan merendahkan tubuhnya seakan membentuk kuda-kuda. Kedua tangannya mengepal dan menyiku tajam. Mulutnya terbuka lebar. Di atas kepalanya terdapat guratan garis spiral hitam. Terdapat pop-up teks berlatar hitam yang keluar dari sosok itu. Teks berwarna putih itu bertuliskan: "SO WHAT, YOU RUN AWAY ? YOU'RE AFRAID TO FIGHT?" Jika diterjemahkan berarti, "Jadi apa, anda melarikan diri? Anda takut untuk melawan?" 55 Dari teks tersebut dapat

54. Cambridge Dictionary, s.v. "When the muslim fasts," https://dictionary.cambridge.org/translate/. (diakses tanggal 27 November, 2020).

55. Ibid. dijadikan sebagai petunjuk makna, bahwa jarak antar dua kaki kuda-kuda dan siku tajam kepalan tangannya merupakan bentuk ekspresi marah dari sosok tersebut. Hal ini, diperkuat pula dengan mulut yang terbuka lebar seperti sedang berteriak dan guratan spiral di atas kepala seperti sedang mengalami gejolak emosi yang rumit. Sosok pertama ini digambarkan sebagai orang yang menyulut amarah seseorang untuk berkelahi.

Sosok kedua, berada di depan sosok pertama. la mengenakan kemeja, berbeda dengan tiga sosok lain yang mengenakan kaos. Sosok ini berdiri menghadap depan. Tangan kanannya memegang gelas yang di atasnya tampak keluar seperti asap. Mulutnya terbuka sedikit. Terdapat pop-up teks berlatar hitam yang keluar dari sosok itu. Teks berwarna putih itu bertuliskan: "A COFFE, COLLEGUE. COME ON, IT WON'T HARM YOU..." Jika diterjemahkan berarti: "Sebuah kopi, teman. Ayolah, ini tidak akan membahayakan anda." ${ }^{56}$ Dari teks tersebut dapat dijadikan sebagai petunjuk makna bahwa kemeja yang dikenakan sosok kedua menggambarkan bahwa ia merupakan teman dari orang yang diajak bicara. Sedangkan, gelas dan tanda asap di atas gelas menandakan kopi yang hendak ditawarkan kepada lawan bicara. Sosok kedua ini digambarkan sebagai teman kerja yang sedang merayu seseorang untuk meminum kopi.

Sosok ketiga, berada di depan sosok kedua. Sosok ini berdiri menghadap depan. Tangan kanannya memegang benda kotak kecil,

\footnotetext{
56. Cambridge Dictionary, s.v. "A coffee, collegue. Come on, it won't harm you," https://dictionary.cambridge.org/translate/. (diakses tanggal 27 November, 2020).
} 
tangan kirinya menunjuk pada benda itu. Mulutnya membuka sedikit lebar. Terdapat pop-up teks berlatar hitam yang keluar dari sosok itu. Teks berwarna putih itu bertuliskan: "LOOT AT THIS PICTURE. NOT SO BAD HEIN? HE HE HE" Kira-kira berarti: "Lihatlah pada gambar ini. Tidak begitu buruk kan? He He He." ${ }^{157}$ Dari teks tersebut dapat dijadikan sebagai petunjuk makna bahwa benda yang diangkat sosok itu berisi tentang gambar. Dan jari telunjuk yang mengarah ke benda itu adalah upaya mengarahkan fokus lawan bicara pada titik yang dituju. Sosok ketiga ini digambarkan sedang merayu lawan bicaranya untuk melihat suatu gambar.

Sosok keempat, berada di depan sosok ketiga. Sosok ini menghadap depan. Jarak antara kedua kakinya sangat lebar hingga seperti membuat kuda-kuda. Tangan kanannya membuka di sebelah kanan pipi, tangan kirinya menggaruk ke arah depan. Terdapat guratan garis hitam di belakang punggung badannya dan di punggung tangan kirinya. Terdapat teks hitam di atas kepala sosok keempat ini, teks itu bertuliskan: "WAIT, DON'T YOU WANT TO KNOW THE LATEST NEWS? IT SEEMS THAT..." Kira-kira berarti: "Tunggu, kau ingin tahu berita terbaru? Tampaknya..." ${ }^{58}$ Dari teks tersebut, dapat dijadikan sebagai petunjuk makna bahwa sosok keempat berusaha merayu lawan bicara agar mendengarkan tentang suatu berita terbaru, namun isi berita yang dibicarakan adalah suatu dugaan dan belum lengkap isinya.

Selain empat sosok tersebut, terdapat sosok siluet hitam laki-laki yang berbeda. Sosok ini

\footnotetext{
57. Ibid.
}

58. Ibid. berjanggut mengenakan baju putih lengan panjang, peci bundar di kepalanya dengan warna senada, dan celana panjang hitam yang digulung hingga sekira di atas mata kaki. Tangan kanannya menjuntai mengepal, tangan kirinya berkibas kebelakang. Jarak antara kedua kakinya panjang seperti sedang berjalan. Terdapat guratan garis melengkung terbuka di antara dua kakinya, di belakang kaki kanannya, serta di siku-lengan tangan kirinya.

Mulut laki-laki itu sedikit terbuka. Terdapat pop-up teks berlatar putih yang keluar dari sosok laki-laki itu. Teks berwarna hitam itu bertuliskan: “NO THANKS, I'M FASTING." Jika diterjemahkan berarti: "Tidak terima kasih, saya berpuasa." 59 Di bagian bawah strip terdapat teks besar berwarna putih serupa dengan tipografi di bagian atas strip. Teks ini bertuliskan: "THIS IS HIS ENTIRE BODY THAT FASTS." Jika diterjemahkan berarti: "Ini adalah seluruh tubuhnya yang berpuasa." ${ }^{60}$

Jika merujuk pada teks pada bagian di bawah, maka hal ini dapat menjadi petunjuk makna bagi sosok siluet kelima yang berbeda dengan empat sosok di belakangnya. Bahwa teks "NO THANKS...." merupakan suatu jawaban terhadap empat sosok sebelumnya. Jawaban penolakan terhadap provokasi perkelahian, rayuan minum, rayuan melihat gambar tertentu, dan rayuan untuk mendengarkan isu tak berdasar; saat sedang melakukan puasa. Bahwa penolakanpenolakan itu berarti seseorang yang sedang berpuasa adalah orang yang mengendalikan amarah, menahan rasa haus, menjaga

\footnotetext{
59. Cambridge Dictionary, s.v. "This is His Entire Body Fasts," https://dictionary.cambridge.org/translate/. (diakses tanggal 27 November, 2020).

60. Ibid.
} 
pandangan, serta menghindari pergunjingan.

Hal ini, dapat dipahami sebagaimana penjelasan Elly Marlina bahwa Puasa merupakan madrasah moralitas yang besar dan dapat dijadikan sarana latihan untuk menempa berbagai macam sifat terpuji. Puasa adalah jihad melawan hawa nafsu, manangkal godaan-godaan dan rayuanrayuan setan yang terkadang terlintas dalam pikiran. Puasa bisa membiasakan orang bersikap sabar terhadap hal-hal yang diharamkan, penderitaan, dan kesulitan yang muncul dihadapannya. ${ }^{61}$

Termasuk godaan/rayuan seperti penggambaran dalam strip ini yang berisi berbagai macam bisikan agar membatalkan puasanya.

\section{Komik Strip "Sense During Ramadan"}

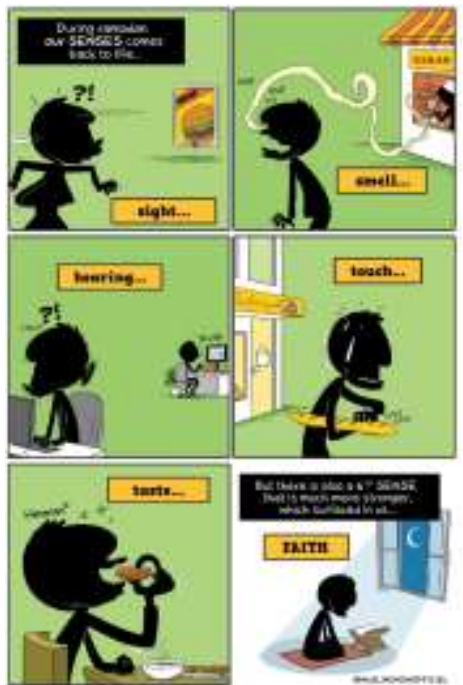

Gambar 5 Inderawi Kala Ramadan, Sumber: https://web.facebook.com/themuslimshow/posts/208 8707704584626

\begin{tabular}{lll}
\multicolumn{2}{c}{ Tabel 5 Identifikasi Tanda dalam Komik Strip Lima } \\
\hline Jenis & \multicolumn{1}{c}{ Identifikasi } \\
\hline Ikon & 1. & Sosok pria hitam. \\
& 2. & Burger. \\
& 3. & Kebab. \\
& 4. & Roti. \\
& 5. & Kurma. \\
& 6. & Kitab Al-Qur'an. \\
& 7. & Bangunan toko. \\
& 8. & Meja dan kursi. \\
Indeks & 9. Jendela. \\
& 1. & Bahasa tubuh teratensi. \\
& 2. Bahasa tubuh mencium bau. \\
& 3. Bahasa tubuh meraba. \\
& 4. Bahasa tubuh makan. \\
5imbol & 1. Bahasa tubuh menunduk. \\
& 2. Teks berlatar hitam. \\
&
\end{tabular}

Pada panel pertama. Terdapat bingkai teks putih berlatar hitam bertuliskan: "During ramadan our SENSES comes back to life..." Jika diterjemahkan berarti: "Selama ramadan, indera kita hidup kembali." 62 Di bawahnya terdapat sosok siluet hitam lelaki yang mengangkat kedua siku tangannya sejajar pundak, namun menggantungkan kedua kepal tangannya ke bawah. Wajahnya menghadap pada suatu papan dengan gambar burger besar dan terdapat teks "NEW" di atas burger itu. Di atas kepala lelaki itu terdapat pungtuasi tanda tanya dan seru "?!" Di belakang kepala lelaki itu terdapat guratan garis melengkung horizontal berwarna putih.

Terdapat bingkai teks hitam berlatar kuning bertuliskan "sight..." di pojok kanan bawah panel pertama ini. Teks ini dapat menjadi petunjuk makna terhadap tanda-tanda yang digambarkan dalam sosok lelaki di panel ini. Wajah yang menghadap papan bergambar

62. Cambridge Dictionary, s.v. "During ramadan our senses comes back to life," https://dictionary.cambridge.org/translate/. (diakses tanggal 27 November, 2020).
61. Elly Marlina, "Motivasi Berpuasa Ramadhan dan Moralitas Remaja," Ilmu Dakwah: Academic Journal for Homiletic Studies, Vol. 6, No. 2 (Desember 2012), 261. (249-265), https://doi.org/10.15575/idajhs.v6i2.337. doi: 
burger berarti tatapan mata si lelaki menaruh atensi terhadap papan itu. Guratan garis melingkar di belakang kepala berarti si lelaki membuat gerakan menoleh dari yang awalnya tidak melihat papan menjadi melihat papan. Tanda pungtuasi di atas kepala lelaki dan sudut lengan yang dibuat berarti si lelaki belum fokus benar dan masih mencerna konten yang ada di dalam papan itu. Panel satu ini pada akhirnya menggambarkan sosok yang sedang berpuasa jadi lebih teratensi dengan gambar makanan.

Pada panel kedua. Terdapat suatu tanda seperti halnya bangunan dengan jendela dan atap yang berwarna-warni merah-kuning. Terdapat bingkai berlatar kuning bertuliskan merah di antara atap dan jendela bangunan itu, isi teksnya: "KEBAB" Dalam bingkai jendela terdapat tanda sosok siluet hitam berkopiah putih yang sedang menghadap benda tabung besar berwarna coklat. Jika merujuk pada teks KEBAB, maka benda ini adalah daging kebab yang masih belum dikemas. Keluar tanda yang menyerupai asap panjang mengular masuk ke hidung sosok kedua di luar bangunan itu. Sosok ini adalah siluet hitam laki-laki. Badannya sedikit membungkuk dan tangannya menjuntai ke bawah. Mulutnya menganga lebar. Di atas kepalanya terdapat teks bertuliskan: "snif, snif, snif."Terdapat bingkai berlatar kuning bertuliskan teks hitam: "smell..." di antara bangunan itu dan sosok di luarnya. Teks ini begitu juga dengan teks berlatar hitam pada panel pertama dapat menjadi petunjuk makna bahwa indera penciuman lelaki yang sedang berpuasa di luar menjadi peka terhadap bau daging kebab di dalam bangunan.
Pada panel ketiga. Terdapat sosok siluet hitam lelaki yang duduk di kursi. Di hadapannya terdapat benda serupa laptop yang diletakkan di atas meja putih. Kedua tangannya berada di atas laptop tersebut. Namun, wajahnya tak tampak menghadap layar laptop. Di bawah dagunya terdapat guratan garis putih melengkung vertikal. Di atas kepalanya terdapat pungtuasi tanda tanya dan tanda seru ?!. Juga terdapat teks hitam bertuliskan: “*chips?" atau bisa juga kira-kira diartikan: "keripik kentang?" Telinga kirinya membesar. Jauh di belakangnya terdapat sosok yang sama, hanya saja kedua sosok ini saling berpunggung badan. Lelaki kedua ini wajahnya tampak menghadap benda seperti layar komputer di hadapannya. Tapi tangannya sedang memegang benda bundar kecil coklat. Di depan layar komputernya juga terdapat benda coklat, yang jika merujuk pada teks chips pada sosok pertama, maka benda ini dapat diartikan sebagai bungkus serta isi keripik kentang. Terlebih terdapat guratan garis abstrak dari bungkus keripik kentang ini ke atas disertai dengan teks bertuliskan "Krak" Agaknya telinga kiri yang membesar, guratan garis putih di bawah dagu, serta pungtuasi "?!" yang digambarkan melekat pada sosok pertama merupakan bentuk kagetnya sosok pertama mendengar suara "Krak" yang bersumber dari keripik kentang sosok kedua. Terlebih hal ini dikuatkan dengan adanya bingkai berlatar kuning dan berisi teks hitam bertuliskan "hearing" di atas kedua sosok ini. Jika dikaitkan dengan tulisan berlatar hitam di panel pertama, maka indera pendengaran pada sosok pertama di panel ketiga ini bermakna meningkatnya indera pendengaran orang yang sedang berpuasa terhadap suara-suara yang berhubungan dengan makanan. 
Pada panel keempat. Terdapat sosok siluet hitam lelaki berjanggut yang sedang berdiri. Tangan kanannya mengempit benda menyerupai roti berukuran panjang. Tangan kirinya menggaruk bagian atas roti itu. Terdapat pula teks bertuliskan "crrr, crrr" di area dekat tangan kirinya. Di daerah pelipis kepalanya ada guratan garis putih seperti air. Jika merujuk pada tanda semacam bangunan di belakang sosok itu, serta papan bertuliskan "Bakery" yang menempel pada bangunan itu, maka benda yang dipegang oleh lelaki itu memang roti. Dan tangan kirinya memang sedang menggaruk permukaan roti. Terdapat bingkai besar berlatar kuning berteks hitam dengan isi tulisan: "touch" $\mathrm{Hal}$ ini berarti panel keempat, jika dihubungkan pula dengan tulisan berlatar hitam pada panel pertama, merupakan penggambaran atas meningkatnya indera peraba seseorang yang berpuasa khususnya terhadap makanan.

Pada panel kelima. Terdapat sosok siluet hitam lelaki berjanggut yang seperti sedang duduk di atas kursi, hanya saja bagian perut ke atas saja yang tampak. Di depannya terdapat benda putih seperti mangkok yang di atasnya terdapat guratan garis menyerupai asap, di sebelah mangkok itu terdapat tiga bulatan berwarna coklat muda di atas benda putih menyerupai piring. Mangkok dan piring ini berada di atas meja. Lelaki itu menyikukan tangan kirinya di atas meja, sedangkan ibu jari dan telunjuk tangan kanannya memegang bulatan coklat muda yang diarahkan ke dalam mulutnya. Mulutnya pun sedang terbuka selebar bulatan itu. Di atas kepalanya terdapat guratan garis hitam serupa bintang, terdapat teks bertuliskan: "Hmmm"

Di bagian pojok kanan atas terdapat bingkai berlatar kuning bertuliskan teks hitam: "taste..." Jika merujuk pada teks latar hitam pada panel pertama juga teks yang terdapat dalam panel kelima ini, maka tanda-tanda yang digunakan jadi memiliki arti. Bahwa salah satu indera manusia yang kembali hidup adalah indera perasa yang disimbolkan dengan bulatan coklat muda yang berarti kurma, mulut yang menganga sebagai indera perasa, serta teks " $\mathrm{Hmmm}$ " dan bintang-bintang sebagai wujud ekspresi rasa.

Pada panel keenam. Terdapat sosok siluet hitam lelaki berjanggut memakai gamis yang sedang duduk bersila dengan menaruh siku kedua tangannya di masing-masing lututnya. la duduk di atas benda persegi panjang merah muda menyerupai sajadah. la menunduk menghadap ke arah benda semacam mushaf Al-Qur'an yang berada di atas meja mengaji. Di hadapannya terdapat pula benda menyerupai jendela yang terbuka. Di dalamnya terdapat warna biru gelap seperti gelap malam sinar rembulan bertabur bintang. Ada pula warna biru muda yang keluar dari jendela itu mengarah pada sosok lelaki seperti sinar malam dari luar jendela yang menembus hingga ke dalam ruangan. Terdapat dua teks dengan latar berbeda. Pertama, posisi bingkai berada sedikit di atas lelaki. Bingkai ini berlatar kuning bertuliskan teks berwarna hitam: "FAITH." Kedua, posisi bingkai berada di bagian atas panel. Bingkai ini berlatar hitam bertuliskan teks berwarna putih: "But there is also 6th SENSE that is much more stronger, which surfaced in us..." Jika diterjemahkan berarti: "Tapi ada juga indera keenam yang 
jauh lebih kuat, yang muncul di dalam diri kita..." ${ }^{\prime 63}$

Dari kedua teks itu, pun juga jika dihubungkan dengan teks berlatar hitam di panel satu, terdapat hubungan khususnya akibat dari kata "But" atau "Tapi." Bahwa lazimnya indera manusia dikenal berjumlah lima, terbagi dalam lima panel, yakni penglihatan, penciuman, pendengaran, peraba, dan parasa. Namun juga terdapat indera lain yang semakin menguat di bulan Ramadan yakni keimanan. Keimanan di sini digambarkan dengan sosok muslim yang khusyuk mengaji di malam hari. Sosok muslim dari gamis dan janggutnya. Kekhusyukan dari sikap duduk bersila dan menundukkan kepala. Mengaji dari adanya artefak tanda mushaf Alquran di atas meja khusus yang sedang dilihat oleh sosok lelaki muslim itu. Sedangkan, malam hari dari tanda bintang rembulan dalam bingkai jendela. Penandaan visual dalam strip ini tak bisa dilepaskan dari adanya suatu konsep bahwa ketika berpuasa, seseorang sedang dilatih untuk menjaga pandangan, pendengaran dan pembicaraan yang buruk, sehingga semua panca inderanya terbiasa dalam kontrol dirinya. Sederhananya, puasa adalah menjaga seluruh panca indera dari segala maksiat. ${ }^{64}$

Sedangkan di sisi lain, keimanan adalah suatu hal yang terus dijaga dalam menghadapi berbagai macam ujian khususnya ketika sedang berpuasa. Sebab, Allah akan senantiasa menguji keimanan seseorang supaya dapat dibedakan mana

63. Cambridge Dictionary, s.v. "But there is also 6th sense that is much more stronger, which surfaced in us," https://dictionary.cambridge.org/translate/. (diakses tanggal 27 November, 2020).

64. Cholil Nafis, Menyingkap Takbir Puasa Ramadhan (Jakarta: Mitra Abadi Press, 2015), 100 dan 193. yang benar-benar beriman dan mana yang sekedar pengakuan lisan. ${ }^{65}$

\section{Komik Strip "During Taraweeh"}

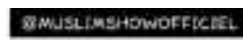

\section{During Taraweeh...}

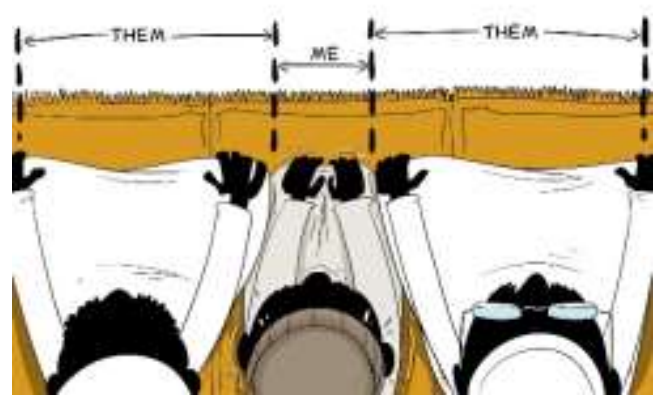

Gambar 6 Ketika Tarawih, Sumber:

https://web.facebook.com/themuslimshow/posts/209 2306610891402

Identifikasi tanda pada komik strip satu adalah sebagai berikut:

Tabel 6 Identifikasi Tanda dalam Komik Strip Enam

\begin{tabular}{|c|c|}
\hline Jenis & Identifikasi \\
\hline Ikon & $\begin{array}{l}\text { 1. Sosok pria hitam berbaju agak } \\
\text { keabu-abuan. }\end{array}$ \\
\hline & $\begin{array}{l}\text { 2. Dua sosok pria hitam berbaju } \\
\text { putih. }\end{array}$ \\
\hline
\end{tabular}

Indeks Bahasa tubuh menyempitkan jarak lutut duduk tahiyat.

Simbol 1. Teks "Me" dan "Them".

2. Teks "During Taraweeh".

Latar strip ini berwarna putih. Ada teks besar berada di bagian atas strip, teks ini bertuliskan: "During Taraweeh..." Jika diterjemahkan berarti: "Ketika salat tarawih..." ${ }^{\prime 66}$

65. Zaprulkhan, Puasa Ramadhan Sebagai Terapi Pencerahan Spiritual (Jakarta: Hikmah, t.th), 127. 66. Cambridge Dictionary, s.v. "During Taraweeh...," https://dictionary.cambridge.org/translate/. (diakses tanggal 27 November, 2020). 
Terdapat tiga sosok siluet hitam lelaki yang seperti sedang duduk bersila menghadap depan. Kedua telapak tangan masing-masing tokoh ini di memegang lutut masing-masing. Strip ini mengambil sudut pandang dari atas kepala tiga sosok ini. Sosok pertama mengenakan gamis berwarna putih sama seperti sosok ketiga. Perbedaan di antara keduanya hanya pada sosok pertama mengenakan peci tak bergaris serta tak gunakan kaca mata, sedangkan sosok kedua pecinya bergaris dan menggunakan kaca mata.

Sedangkan sosok kedua, posisinya diapit di tengah sosok pertama dan ketiga. Warna baju gamis dan pecinya abu-abu. Namun ketika duduk bersila, kedua lutut sosok ini seperti saling bertemu. Berbeda dengan sosok pertama dan ketiga yang posisi kedua lutut masing-masingnya sangat lebar berjauhan. Hal ini di dukung dengan indeks garis-garis yang memberi batas ukuran jika lebar lutut sosok pertama dan ketiga lebih lebar daripada sosok kedua. Sosok pertama dan ketiga disimbolkan dengan teks: "THEM." Sedangkan sosok kedua disimbolkan dengan teks: "ME."

Di bawah para sosok itu terdapat benda serupa sajadah berwarna kuning. Terdapat garis-garis hitam yang membagi sajadah itu menjadi tiga bagian. Nampak lutut sosok pertama dan ketiga melampaui garis sajadah miliknya masing-masing. Sedangkan, sosok kedua hanya mendapat bagian yang sedikit. Jika antar tanda ini dihubungkan, maka ketiga sosok tersebut merupakan gambaran

67. Muhammad Mahmud Nasution, "Tarawih dan Tahajjud (Tinjauan Persamaan Dan Perbedaan Dalam Pelaksanaan dan Keutamaan)," FITRAH, Vol. 01, No. 02 (2015), 219. (219-228), doi: https://doi.org/ 10.24952/fitrah.v1i2.315 orang yang sedang melakukan tarawih berjamaah. Menghadap ke arah yang sama, duduk tahiyat di atas sajadah, dan meletakkan kedua tangannya di atas lututnya. Namun secara khusus, teks During atau ketika, menandakan bahwa kejadian itu sedang berlangsung. Hal yang sedang berlangsung adalah diambilnya hak sosok kedua untuk melebarkan lututnya ketika sedang duduk tahiyat. Dan hal ini, merupakan suatu masalah sebab terdapat tanda guratan garis hitam-putih di sekitar tangan sosok kedua, serta guratan garis seperti keringat yang keluar dari kepala sosok kedua.

Sehingga secara umum, strip enam ini hendak menggambarkan tarawih ketika Ramadan biasa dilakukan secara berjamaah dan terdapat cerita dinamika ketika melaksanakannya. Salah satu dinamika yang terjadi adalah berdesakan dalam hal jarak lutut ketika duduk tahiyat. Tentu hal ini merupakan hal yang biasa terjadi ketika melaksanakan ibadah tarawih. Sebab memang Nabi mencontohkan tarawih berjamaah di masjid, meski hanya beberapa kali agar tidak dianggap sebagai wajib; sebagaimana penjelasan Nasution. ${ }^{67}$ Dan tentu bergantung dari jamaah yang hadir serta kapasitas masjid, sehingga berdesakan memungkinkan terjadi. Seperti halnya, gambaran tradisi Massilumba Oroang di salah satu daerah di Indonesia, yakni 'mengkavling' saf dengan sajadah seusai salat magrib agar tidak berdesakan dan kebagian tempat ketika tarawih nanti. ${ }^{68}$

\footnotetext{
68. Junaedi, "Massilumba Oroang, Tradisi "Kaveling" Tempat Shalat Tarawih di Masjid Polewali Mandar," kompas.com,https://regional.kompas.com/read/2018 /05/20/15541261/massilumba-oroang-tradisikaveling-tempat-shalat-tarawih-di-masjid-polewali.L. (diakses tanggal 11 Januari, 2021).
} 


\section{Komik Strip "Students Life During Ramadan"}

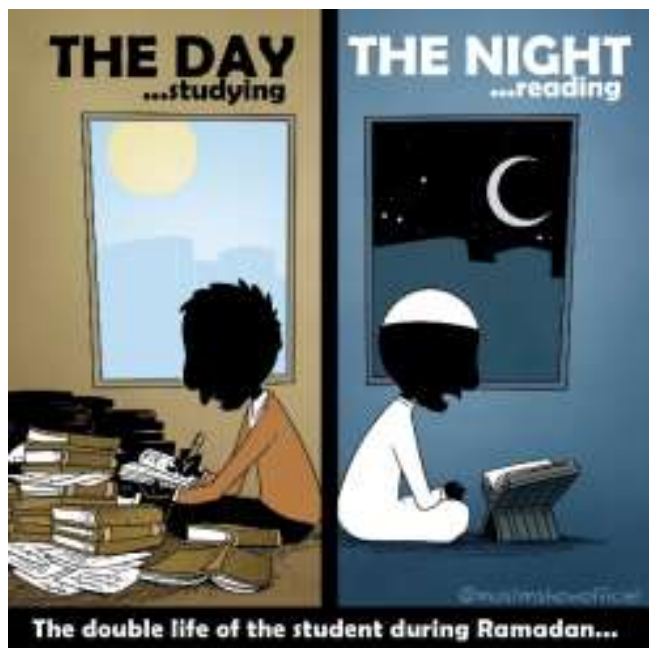

Gambar 7 Kehidupan Pelajar Kala Ramadan, Sumber: https://web.facebook.com/themuslimshow/posts/209 8939893561407

Tabel 7 - Identifikasi Tanda dalam Komik Strip Tujuh

\begin{tabular}{ll}
\hline Jenis & \multicolumn{1}{c}{ Identifikasi } \\
\hline Ikon & 1. Sosok pria hitam baju krem. \\
& 2. Dua sosok pria hitam baju dan \\
& peci putih. \\
& 3. Tumpukan buku-buku. \\
& 4. Mushaf Al-Qur'an. \\
& 5. Mentari dan Bulan. \\
Indeks & Bahasa tubuh menulis dan membaca. \\
Simbol & 1. Teks keterangan waktu. \\
& 2. Teks dua kehidupan.
\end{tabular}

Panel pertama di sebelah kiri dominan berlatar warna coklat, sedangkan panel kedua warna biru gelap, terdapat garis tebal hitam sebagai pembatas di antara keduanya. Pada panel pertama, sisi kiri, terdapat teks hitam bertuliskan: "THE DAY ...studying." Juga terdapat sosok siluet hitam lelaki berjanggut. la sedang berada di dalam suatu ruangan, sebab tampak terdapat bingkai besar layaknya jendela. Di dalam bingkai tersebut terdapat bulatan kuning layaknya matahari jika coba dihubungkan dengan petunjuk dalam teks THE DAY sebelumnya yang berarti siang hari. Dan juga terdapat siluet bangunan gedung di bawah matahari itu. Lelaki itu mengenakan kemeja putih berkerah yang dilapis dengan sweater lengan panjang berwarna coklat muda. Bercelana panjang berwarna hitam. Tangan kirinya memegang benda seperti buku, tangan kanannya memegang benda seperti bolpoin. Lelaki itu mengarahkan bolpoin ke arah buku yang di pegangnya. Jika merujuk pada teks "...studying" perilaku lelaki ini merupakan tanda bahwa ia sedang belajar atas suatu hal. Terlebih pula terdapat tumpukan banyak buku serta kertas-kertas di hadapannya.

Pada panel kedua kanan, terdapat teks putih bertuliskan: "THE NIGHT ...reading." Juga terdapat sosok siluet hitam lelaki berjanggut. la berada di dalam suatu rangan, sebab tampak terdapat bingkai besar layaknya jendela. Di dalam bingkai tersebut terdapat simbol bulan sabit berwarna putih layaknya bulan jika coba dihubungkan dengan petunjuk dalam teks THE NIGHT sebelumnya yang berarti malam hari. Dan juga terdapat titik-titik putih serupa bintang dengan siluet gedung di bawahnya. Lelaki itu mengenakan gamis putih panjang dan peci bundar putih. la duduk bersila. Siku tangannya ditempatkan pada pangkal pahanya. Sedangkan, tangannya mengepal disekitar lutut. Mulutnya terbuka wajahnya menunduk menghadap benda seperti mushaf Alquran yang berada di atas meja mengaji di hadapan lelaki itu. Jika merujuk pada teks "...reading," maka lelaki itu digambarkan sedang membaca mushaf Alquran.

Di bagian bawah strip terdapat teks putih berlatar hitam bertuliskan: "The double life of the student during Ramadan..." Jika diterjemahkan berarti: "Kehidupan ganda 
pelajar selama Ramadan." ${ }^{69}$ Teks ini dapat menjadi petunjuk makna bahwa sosok lelaki yang ada di dalam dua panel di atasnya merupakan sosok yang sama. Kehidupan yang dimaksud adalah ketika di siang hari pelajar itu sedang belajar, sedangkan di malam hari pelajar itu sedang membaca mushaf Alquran atau mengaji. Secara tersirat seperti menggambarkan kehidupan belajar sebagai dilakukan pada siang hari, lalu kegiatan ibadah dilakukan pada malam hari.

Hal ini berkaitan dengan temuan Oosterbak dan Klaauw terkait tantangan yang dihadapi oleh para pelajar muslim, dimana aktivitas ibadah saat ramadan dianggap memberi dampak negatif terhadap performa akademik, khususnya yang hidup di lingkungan mayoritas non-muslim. ${ }^{70}$ Namun, meski begitu pelajar di bulan Ramadan masih tetap terus belajar dan beribadah baik di siang maupun malam hari karena menjalankan ibadah di bulan Ramadan adalah selain untuk menjaga hubungan baik dengan Allah Swt, juga memiliki nuansa memperbaiki hubungan baik kepada sesama manusia. Salah satunya adalah ibadah ritual membaca Alquran yang dapat menjadi penenang bagi setiap pembacanya sehinga terbina kesabaran dan pengendalian diri dalam kerangka emosi positif. ${ }^{71}$

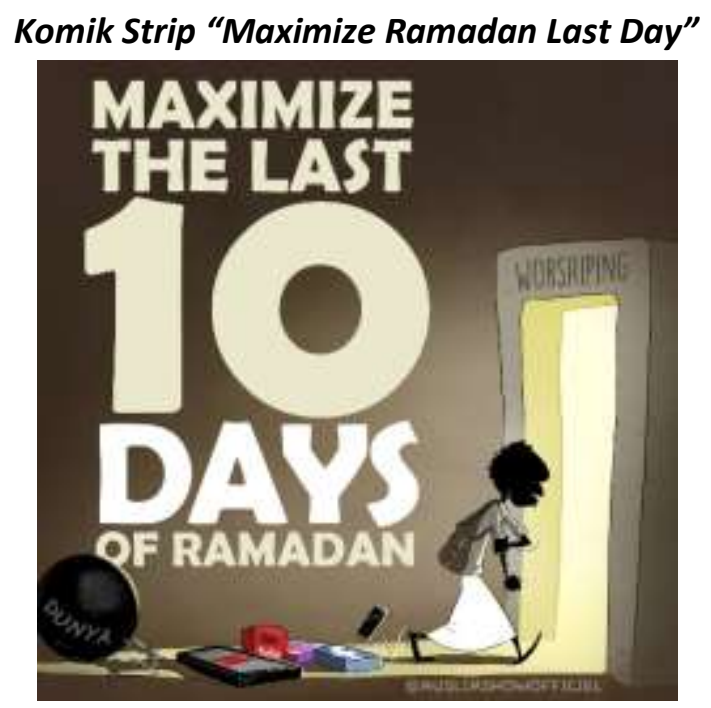

Gambar 8 Memaksimalkan Akhir Ramadan, Sumber: https://web.facebook.com/themuslimshow/posts/211 3636038758459

Tabel 8 Identifikasi Tanda dalam Komik Strip Delapan

\begin{tabular}{|c|c|}
\hline Jenis & Identifikasi \\
\hline Ikon & $\begin{array}{l}\text { 1. Sosok pria hitam baju krem. } \\
\text { 2. Gapura bercahaya. } \\
\text { 3. Bola hitam. }\end{array}$ \\
\hline Indeks & $\begin{array}{l}\text { Bahasa tubuh menggulung lengan } \\
\text { baju pada tangan kanan. }\end{array}$ \\
\hline Simbol & $\begin{array}{l}\text { 1. Logo-logo sosial media. } \\
\text { 2. Teks "10 Days of Ramadan". } \\
\text { 3. Teks "DUNYA". } \\
\text { 4. Teks "Worshipping". }\end{array}$ \\
\hline
\end{tabular}

Latar strip ini dominan berwarna coklat gelap. Terdapat teks besar hampir memakan separuh panel. Teks ini berwarna coklat muda bertuliskan: "MAXIMIZE THE LAST 10 DAYS OF RAMADAN." Jika diterjemahkan berarti: "Maksimalkan 10 hari terakhir Ramadan."

Shahabah Jurnal Pendidikan dan Studi Islam, Vol. 2, No. 1 (2016), 95-96, doi: http://journal-uimmakassar.ac.id/index.php/ASH/article/view/164/126 72. Cambridge Dictionary, s.v. "Maximize the last 10 days of ramadan," https://dictionary.cambridge.org/translate/. (diakses tanggal 27 November, 2020). 
Terdapat sosok siluet hitam lelaki yang seperti sedang melangkah menuju gapura besar dan meninggalkan beberapa benda di belakangnya. Lelaki berjanggut ini mengenakan kaos abu-abu lengan panjang yang digulung sebatas siku tangan. la mengenakan semacam rok atau sarung berwarna putih. Serta di punggung, ia membawa tas ransel berwarna coklat gelap. Tangan kirinya menggenggam siku kanannya. Di hadapannya terdapat gapura besar sepertinya terbuat dari batu jika merujuk pada warna abu-abu dan coklat gelap yang digunakan. Tinggi gapura ini hampir dua kali lipat tinggi sosok lelaki. Di bagian atas gapura terdapat teks bertuliskan: "Worshiping" yang kira-kira berarti beribadah. Dalam gapura ini terdapat warna kuning cerah seakan muncul dan menyinari sosok lelaki hingga membentuk bayangan yang segaris dengan arah cahaya. Di belakang lelaki ini terdapat berbagai macam benda. Ada bulatan besar hitam dengan rantai abu-abu di ujungnya. Di dalam bulatan ini bertuliskan: "DUNYA." Juga terdapat benda serupa smartphone dengan isi huruf $\mathrm{N}$ berwarna merah seperti logo Netflix. Ada pula tiga balok-kubus yang masing-masing berisi teks You Tube, $F$, dan logo Instagram. Juga terdapat benda smartphone yang tidak tergeletak seperti benda-benda lainnya. la seperti terjatuh jika merujuk pada guratan garis menyerupai centang di bagian depannya.

Jika dihubungkan, maka teks dalam strip ini dapat menjadi petunjuk. Bahwa memaksimalkan 10 hari terakhir bulan ramadan yang dimaksud di sini adalah umat muslim yang meninggalkan beban berat urusan dunia, serta meninggalkan urusan sosial media dalam smartphone seperti Netflix, Facebook, You Tube, dan Instagram. Semua ini ditinggalkan menuju suatu hal yang lebih mencerahkan, yakni beribadah. Tidak dispesifikkan memang, ibadah yang perlu dioptimalkan dalam bentuk apa pada penggambaran visual ini. Sehingga dapat saja dimaknai seluruh ibadah baik dalam bentuk habluminallah maupun habluminannas.

Selain itu, mengoptimalkan ibadah di sepuluh hari terakhir Ramadan dapat dilakukan dengan berdasarkan ilmu sebagaimana cahaya yang mencerahkan. Seperti yang dipaparkan oleh Naser Muhammad bahwa ia membuat buku berjudul "Menggapai Mulia Ramadan dengan IImu" agar pembaca tidak hanya mengisi Ramadan dengan rutinitas yang semu tanpa menjiwai ibadah didalamnya. la mengutip sabda Rasulullah bahwa betapa banyaknya orang yang menjalani ramadan dengan susah payah bergelut dengan panas mentari tapi tak ada yang didapatkan dari puasa juga tak meraih pahala kecuali lapar dan dahaga saja. ${ }^{73}$

\section{Kesimpulan}

Penggunaan ikon yang khas dengan mudah diidentifikasikan pada Islam kerap digunakan dalam strip ini; seperti peci, gamis, jilbab, kurma, mushaf Alquran, dan sebagainya. Namun, juga terdapat ikon kehidupan sehari-hari di jaman modern ini, seperti logo sosial media, komputer, burger, roti tawar, dan sebagainya. Ikon-ikon tersebut selanjutnya, oleh sang komikus diberi pemaknaan dengan memberikan simbol

73. Muhammad Naser, Menggapai Mulia Ramadan dengan Ilmu (Jakarta: Perahu Litera, 2019), 14. 
berupa teks-teks singkat sebagai penjelasan atas visualisasi antar ikon tersebut dalam masing-masing strip.

The Muslim Show menggambarkan bulan Ramadan adalah bulan yang sangat dinanti dengan suka cita dan pasti dilalui oleh umat muslim. Tanda/simbol yang digunakan sebagai sosok tokoh utama adalah janggut atau peci bagi lelaki dan jilbab bagi perempuan. Dalam menjalani bulan Ramadan, umat muslim akan dihadapkan oleh berbagai macam cobaan, baik yang datang dari sesama umat muslim, juga digambarkan pula datang dari diri sendiri dengan tiadanya sosok lain dan digantikan dengan benda/artefak lain.

Secara khusus bulan Ramadan digambarkan bermanfaat untuk mengubur kebiasaan buruk, perlu keimanan yang kuat untuk menempuhnya, banyak tantangan fisik dan psikis yang menyertai baik dalam kehidupan sehari-hari maupun ketika ibadah.
Penggunaan simbol terhadap barang-barang yang sering digunakan orang-orang pada zaman ini, seperti smartphone, sosial media, paket kiriman, tagihan bulanan, kripik kentang, dan selainnya; serta penggunaan berbagai warna sebagai indeks menjadikan komik ini dapat dengan mudah dipahami dan diambil hikmahnya dari berbagai sudut pandang umat muslim di beberapa manca negara, tidak hanya di Perancis tempat komikus tinggal.

Rekomendasi bagi para praktisi dakwah khususnya yang bergerak di bidang komik, perlu dapat membuat simbol-simbol visual yang dapat dengan mudah dipahami baik secara ikon, indeks, atau gambar bahwa simbol tersebut berkaitan dengan konsep ajaran Islam. Serta, juga tidak bertentangan dengan ajaran Islam agar dakwah dapat menjangkau khalayak yang lebih luas khususnya di tengah pesatnya perkembangan teknologi informasi yang mengaburkan batas antar negara ini.

\section{Bibliografi}

Aiello, Giorgia. "Visual Semiotics: Key Concepts and New Directions." Dalam The SAGE Handbook of Visual Research Methods. Edited by Eric Margolis dan Luc Pauwels. London, SAGE Publications. 2011. doi: https://bit.ly/2K4UHQU

Allam, Noredine. "Announcement by Noredine Allam of Muslim Show." BDouin. Februari 8, 2020.

Andrian, Bakti. "Nilai-nilai Pendidikan Islam dalam Pengamalan Puasa Ramadhan Menurut Tafsir Al-Misbah." Skripsi, UIN Raden Intan Lampung, 2019. doi: http://repository.radenintan.ac.id/3510/1/AND.pdf

Anggasta, Maria Goivanie, dan Elda Franzia. "Analisis Semiotika Visual Pada Poster Ngayogjazz 2011-2014," Dimensi, Vol. 13, No. 2 (2015): 177-192. doi: https://trijurnal.lemlit.trisakti.ac.id/dimensi/article/download/57/57

Creswell, John W. dan Dana L. Miller, "Determining Validity in Qualitative Inquiry," Theory Into Practice, Vol. 39, No. 3 (Summer 2000), 124-130. doi: https://doi.org/10.1207/ s15430421tip3903_2 
Caldwell, Joshua. "Comic panel layout: A Peircean analysis," Studies in Comics, Vol. 2, No. 2 (2011): 317-338. doi: https://doi.org/10.1386/stic.2.2.317_1

Cohn, Neil. "Visual Narrative Structure," Cognitive Science 34 (2013): 1-15. doi: https://doi.org/ $10.1111 /$ cogs.12016

Dewi, Murti Candra. "Representasi Pakaian Muslimah dalam Iklan (Analisis Semiotika Charles Sanders Peirce pada Iklan Kosmetik Wardah di Tabloid Nova)," Jurnal Komunikasi Profetik, Vol. 06, No. 2 (Oktober 2013), 63-82. doi: http://ejournal.uinsuka.ac.id/isoshum/profetik/article/download/1171/1081

Harrison, Claire. "Visual Social Semiotics: Understanding How Still Images Make Meaning," Technical Communication, Vol. 50, No. 1 (2003): 46-60. doi: https://bit.ly/38C5xXW

Hidayat, Moh. Andi. "Nilai-nilai Pendidikan Islam dalam Ibadah Puasa Ramadan." Skripsi IAIN Jember, 2016. doi: http://digilib.iain-jember.ac.id/69/6/9.\%20Bab\%20III.pdf

Ibad, Irsyadul. "Nilai-Nilai Kependidikan dalam Pengamalan Ibadah Puasa Ramadan (Kajian AlQur'an Surat al-Baqarah Ayat 183-187)." Skripsi, IAIN Salatiga, 2015. doi: http://erepository.perpus.iainsalatiga.ac.id/217/1/Irsyadul\%20lbad_11111094.pdf

Jayanegara, I Nyoman. "Semitoika Visual Logo RSU Surya Husadha Denpasar," Jurnal Bahasa Rupa, Vol. 1, No. 1 (2017): 11-16. doi: https://doi.org/10.31598/bahasarupa.v1i1.138

Kurniawan, Alhafiz. "Taqarub Tidak Mesti Hari Tertentu," nu.or.id, diakses pada Januari 11, 2021. doi: https://www.nu.or.id/post/read/44991/taqarub-tidak-mesti-hari-tertentu

Marlina, Elly. "Motivasi Berpuasa Ramadhan dan Moralitas Remaja," Ilmu Dakwah: Academic Journal for Homiletic Studies, Vol. 6, No. 2 (Desember 2012), 261. (249-265), doi: https://doi.org/10.15575/idajhs.v6i2.337.

Mukti, Dwiki Nugroho, dan Salamun. "Penciptaan Karya Komik Alternatif," Jurnal Pendidikan Seni Rupa, Vol. 3, No. 2 (2015): 16-22. doi: https://jurnalmahasiswa.unesa.ac.id/ index.php/va/article/download/10512/10225

Nafis, Cholil. Menyingkap Takbir Puasa Ramadhan. Jakarta: Mitra Abadi Press, 2015. doi: http://repository.uinjkt.ac.id/dspace/bitstream/123456789/44299/1/Buku\%20Menyin gkap\%20Tabir\%20Puasa\%20Ramadhan..pdf

Naser, Muhammad. Menggapai Mulia Ramadan dengan Ilmu. Jakarta, Perahu Litera. 2019.

Nasrullah, Rulli, dan Novita Intan Sari, "Komik sebagai Media Dakwah: Analisis Semiotika Kepemimpinan Islam dalam Komik 'Si Bujang'," IImu Dakwah: Academic Journal for Homiletic Studies, Vol. 6, No. 1 (2012): 24-40. doi: http://journal.uinsgd.ac.id/index.php/ idajhs/article/viewFile/325/440

Nasution, Muhammad Mahmud. "Tarawih dan Tahajjud (Tinjauan Persamaan Dan Perbedaan Dalam Pelaksanaan dan Keutamaan)," FITRAH, Vol. 01, No. 02 (2015), 219-228. doi: https://doi.org/10.24952/fitrah.v1i2.315

Oosterbeek, Hessel dan Bas van der Klaauw. "Ramadan, fasting and educational outcomes," Economic Education Review (2013), 1-18. doi: https://doi.org/10.1016/j.econedurev.2012.12.005

Oyama, Rumiko. "Visual Semiotics: A Study of Images in Japanese Advertisements." Disertasi Institute of Education, University of London, 1998. doi: https://discovery.ucl.ac.uk/id/eprint/10019140/7/298112_Redacted.pdf 
Parsa, Alev Fatos. "Visual Semiotics: Key Concepts and New Directions," $2^{\text {nd }}$ International Symposium Communication in The Millenium: A Dialogue. 2004. doi: https://www.academia.edu/download/61794195/Pauwels_Mannay_Chp23_2pp2020 0115-58120-11fus62.pdf

Pease, Allan and Barbara Pease. The Definitive Book of Body Languange: How to read others' thought by their gestures. Australia, Pease International. 2004.

Rahmanadji, Didiek. "Awal Eksistensi Komik Indonesia, Sebagai Produk Budaya Nasional." Universitas Negeri Malang. Februari 8, 2020. doi: http://jurnalonline.um.ac.id/data/artikel/artikel F79F984D53BF7BC7A2D27DA1CFB68F87.pdf.

Rakhmawati, Yuliana. "The Muslim Show: Soft Contra "Labeling" Melalui Media Sosial", Jurnal Komunikasi, Vol. IX, No. 1 (Maret 2015), 1-12. doi: https://ecoentrepreneur.trunojoyo.ac.id/komunikasi/article/viewFile/1147/971

Rasyid, Muh. Haras. "Madrasah Ramadan dalam Dimensi Hablu Min Allah Wa Hablu Min Al-Nas," Ash-Shahabah Jurnal Pendidikan dan Studi Islam, Vol. 2, No. 1 (2016), 90-100. doi: http://journal-uim-makassar.ac.id/index.php/ASH/article/view/164/126

Romario, dan Lisda Aisyah. "Komik Islam Di Media Sosial Instagram: Dakwah Kreatif Melalui Komik," Islamuna, Vol. 6, No. 2 (2019): 98-119. doi: http://ejournal.iainmadura.ac.id/ index.php/islamuna/article/download/2588/1551

Royanullah dan Komari. "Bulan Ramadan dan Kebahagiaan Seorang Muslim," Jurnal Psikologi Islam dan Budaya, Vol. 2, No. 2 (Oktober 2019), 127-138. doi: http://journal.uinsgd.ac.id/index.php/jpib/article/download/5587/3427

Soedarso, Nick. “Komik: Karya Sastra Bergambar," Humaniora, Vol. 6, No. 4 (2015): 496-506. doi: https://journal.binus.ac.id/index.php/Humaniora/article/download/3378/2757

Syam, Essy. "Crayon Shin-Chan: Apakah Komik Jepang Mendidik?" Jurnal Ilmu Budaya, Vol. 5, $\begin{array}{llll}\text { No. } & 1 & \text { (2008), } & \text { 1-100. }\end{array}$ https://journal.unilak.ac.id/index.php/jib/article/view/885/630

Thaib, Hasballah dan Zamakhsyari Hasballah. La'allakum Tattaquun Seratus Satu Jalan Menuju Taqwa Yang Harus Dilatih Selama Ramadhan. Medan, Wal Ashri Publishing. 2014. doi: http://repository.dharmawangsa.ac.id/490/1/laallakum\%20tattaquun.pdf

Tinarbuko, Sumbo. "Semiotika Analisis Tanda Pada Karya Desain Komunikasi Visual", Nirmala, Vol. 5, No. 1 (Januari 2003), 31-47. doi: https://doi.org/10.9744/nirmana.5.1.

Turner, Kathleen J. "Comic strips: A rethorical perspective", Central States Speech Journal, Vol. 28, No. 1 (1977), 24-35. doi: https://doi.org/10.1080/10510977709367916

Zaprulkhan. Puasa Ramadhan Sebagai Terapi Pencerahan Spiritual. Jakarta: Hikmah, t.th.

Zetizen, "Komik Cetak vs Komik Online, Apa Kelebihannya?" Jawapos.com, Januari 6, 2020. doi: https://zetizen.jawapos.com/show/1553/komik-cetak-vs-komik-online-apa-

kelebihannya 
Muhammad Hildan Azizi

326 | INTELEKSIA - Jurnal Pengembangan Ilmu Dakwah 